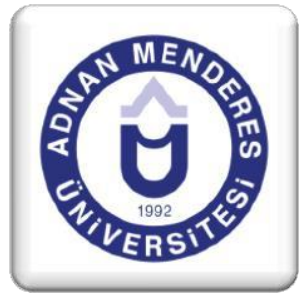

\title{
Şehir ve Bölge Planlama Bölümlerinin Öğretim Kadrolarının TUPOB Ölçütlerine Göre Analizi
}

\author{
Seval CÖMERTLER ${ }^{1}$
}

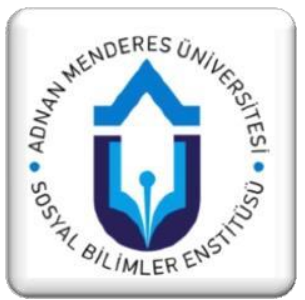

Özet

Planlama eğitiminde kalite ve norm arayışları çerçevesinde, Türkiye Planlama Okulları Birliği (TUPOB) Şehir ve Bölge Planlama (ŞBP) bölümleri için gerekli bir dizi ölçüt belirlemiştir. TUPOB'un 2011 yılında geliştirdiği bu kriterlerin ŞBP bölümlerini yapılandırmadaki etkisini gösteren ve mevcut ŞBP bölümlerinin TUPOB ölçütlerini karşılama durumunu ortaya koyan güncel ve karşılaştırmalı bir çalışma literatüre girmemiştir.

Böyle bir eksiklik doğrultusunda, bu makalenin amacı ŞBP bölümlerini öğretim kadrosu yeterliliği bağlamında TUPOB ölçütlerine göre incelemektir. Araştırma 3 grup olarak sinıflandırılan 21 adet ŞBP bölümünü içermektedir. Çalışmada öğretim kadrosu yeterliliği öğretim üyesi sayısı, öğretim kadrosu çeşitliliği, öğretim üyesi başına düşen birinci sınıf öğrencisi sayısı bağlamında araştırılmıştır. Değişkenlere ilişkin veriler 2016ÖSYS Yükseköğretim Programları ve Kontenjanları Kılavuzundan temin edilmiştir. Değişkenlere betimleyici istatistik analiz teknikleri uygulanmıștır. Analiz bulguları önce gruplar bazında, ardından gruplar arası karşılaştırmalı değerlendirmelerle sunulmuştur.

Analizler TUPOB'un tüm ölçütlerini karşılayan hiç bir grubun ve planlama okulunun bulunmadığını göstermiştir. Sonuç olarak, ŞBP bölümlerinin öğretim kadroları TUPOB kriterlerine göre yetersizdir. Bununla birlikte, yetersizlik dereceleri farklıdır. Üçüncü grup ŞBP bölümleri tüm kriterlere göre en dezavantajlı gruptur. Bulgular, bir ortak akıl çalışması olan TUPOB ölçütlerinin planlama okullarının öğretim kadrolarının geliştirilmesinde belirleyici olamadığına işaret etmektedir.

Anahtar Kelimeler: Şehir ve Bölge Planlama, Planlama Eğitimi, Türkiye Planlama Okulları Birliği (TUPOB)

\section{An Analysis of the Teaching Staffs of the City and Regional Planning Departments in Terms of the TUPOB Criteria}

\begin{abstract}
In the context of the quality and norm studies for the planning education, the Association of Planning Schools of Turkey (TUPOB) developed certain measures, which were essential for City and Regional Planning (CRP) departments. A recent and comparative study, which shows the impact of TUPOB criteria - developed in 2011 in structuring the CRP departments, and reveals whether the existing CRP departments provide the TUPOB measures or not, has not entered into the literature.

In the direction of such a deficiency, the aim of this article was to investigate the CRP departments in terms of the TUPOB criteria in the context of the teaching staff adequacy. The research contained 21 CRP departments which were categorized in 3 groups. In the study, the adequacy of the teaching staff were examined in terms of the number of teaching staffs, the diversity of teaching staff, and the number of first year students per teaching staff. Data was obtained from 2016-OSYS Higher Education Programs and Quota Guide. Descriptive statistical analysis techniques were applied to the variables. Analysis findings were first presented on groups' basis, followed by comparative evaluations between groups.

Analysis showed the absence of any group which met all criteria of TUPOB, moreover that of any planning school. Consequently, the teaching staffs of CRP departments were inadequate according to the TUPOB criteria. However, the degrees of inadequacy were different. The third group CRP departments were the most disadvantaged group according to all criteria. Results indicate that the TUPOB's measures, which were a common mind study, have been not decisive in structuring the teaching staffs of the planning schools.
\end{abstract}

${ }^{1}$ Dr.Öğr.Üyesi, Uşak Üniversitesi, Mimarlık ve Tasarım Fakültesi, Şehir ve Bölge Planlama Bölümü 
Keywords: City and Regional Planning, Planning Education, The Association of Planning Schools of Turkey

\section{Giriş}

Türkiye'de 60'lı yıllara kadar mimarlık eğitiminin bir parçası olarak verilen şehircilik eğitimi, 1961'de ilk defa lisans düzeyinde bağımsız bir bölüm olarak Orta Doğu Teknik Üniversitesi (ODTÜ) Şehir ve Bölge Planlama (ŞBP) bölümünde verilmeye başlanmıştır. 1979-1984 yılları arasında üç büyük şehirde kurulan 5 yeni planlama okulu ODTÜ ŞBP bölümünü takip etmiş̧tir. Yeni açılan planlama okullarıyla birlikte, önceleri yalnızca ODTÜ ŞBP bölümünün deneyimleri üzerinden yapılan planlama eğitimi tartışmaları, bu yeni planlama okullarını da içerecek şekilde yaygınlaşmıştır. 90'lı yıllarda bir yandan planlama eğitimi tartışılmaya devam ederken, bir yandan da planlama okullarının sayısı artmaya devam etmiştir ${ }^{2}$ (TUPOB, 2007; Aru, 2001; Arslan, 1991; Esmer, 1991; İnankul, 1991; Tekeli, 1987; Keleş, 1987).

2000'li yıllarda, küreselleşmenin etkisiyle, dünyadaki yükseköğretimin değişimine koşut, eğitimin kitleselleştirilmesi politikası çerçevesinde ve sosyolojik, ekonomik, siyasi ve ideolojik nedenlerle hemen hemen bütün meslek alanlarında okul sayıları dramatik bir şekilde artmıştır (Günay ve Günay, 2016; Tekneci, 2016; Yılmaz, 2013; Erdem, 2012; Kavak, 2011a; Kavak, 2011b; Özer, 2011; Arap, 2010; Rehber, 2007; Erdem, 2006; Schofer ve Meyer, 2005; Tural, 2004) ${ }^{3}$. Bu süreçte, diğer meslek alanlarında yaşanan agresif büyümeye benzer bir şekilde, planlama meslek alanında da ŞBP bölümlerinin sayısında hızlı ve kontrolsüz bir artış yaşanmıştır. Bu artışla birlikte ŞBP bölümleri tüm ülke sathına yayılmıştır. Ne var ki, yeni kurulan ŞBP bölümlerinde, diğer disiplinlerde olduğu gibi, beşeri ve mekânsal altyapı bağlamında çeşitli sorunlar ve yetersizlikler yaşanmıştır ${ }^{4}$. Planlama okullarının plansız bir şekilde gelişmesi ve ŞBP bölümlerinde gözlemlenen yetersizlikler farklı platformlarda dile getirilmiş olup, bu dönemde Avrupa Birliği’ne uyum süreci çerçevesinde planlama eğitiminde akreditasyon, kalite ve norm tartışmaları da başlamıştır (Gülersoy, 2007; Ercoşkun ve Yalçıner, 2002; Erbaş, 2002; Enlil, 2001).

\footnotetext{
${ }^{2}$ Şehircilik eğitimi ve planlama okullarının gelişimi ile ilgili ayrıntılı bilgi için Keleş'in (1987) Türkiye'de Kentbilim Eğitimi kitabından, "Türkiye Planlama Okulları Birliği 1. Koordinasyon Toplantısı" isimli rapordan (TUPOB, 2005), “Türkiye'de Şehir ve Bölge Planlama Eğitiminde Kalite Geliştirme ve Akreditasyon” isimli rapordan (TUPOB, 2007), Büyükcivelek'in (2016) "Neoliberal Düzende Üniversite, Şehir Planlama Eğitimi ve Devrimci Planlama Üzerine Bir Deneme: ODTÜ Şehir ve Bölge Planlama Örneği” isimli bildirisinden, Yıldız Teknik Üniversitesi tarafından hazırlanan "Şehircilik ve Proje Kürsüsünden Şehir ve Bölge Planlama Bölümüne" isimli kitaptan (2008) ve "Şehircilik - Planlama Eğitimi” ismini taşıyan 13. Dünya Şehircilik Günü Kolokyumu kitabından (1991) yararlanılabilir.

${ }^{3} \mathrm{Bu}$ dönemde, yükseköğretimdeki genişlemeye benzer şekilde yükseköğretimi konu alan araştırmalarda da büyük bir artış yaşanmıştır. Yükseköğretimle ilgili kongre ve sempozyumlar düzenlenmiş, yeni yayın organları faaliyete geçmiştir. Bu gelişmelerin sonucunda dünyada ve Türkiye'de yükseköğretimin genişlemesi, sebepleri, sonuçları üzerine geniş bir literatür oluşmuştur.

${ }^{4}$ Yükseköğretimde genişleme ile birlikte yaşanan sorunlar ve çözüm arayışları için bkz (Özoğlu vd., 2016; Doğan, 2013; Acar, 2012; Karahan ve Karahan, 2012; Özer, 2012; Altınsoy, 2011; Günay, 2011; Anderberg vd., 2009; Hammond ve Churchman, 2008; Tekeli, 2003).
} 
Eğitimde kalite ve norm tartışmaları bağlamında, Türkiye Planlama Okulları Birliği (TUPOB) $)^{5}$ Türkiye'de ŞBP lisans eğitimi verebilmek için gerekli öğretim kadrosu ve fiziki altyapıya ilişkin asgari ölçütlerin eksik olduğu tespitinden hareketle, 2011 yılında çok önemli bir rapor hazırlamıştır. "Lisans Düzeyinde Açılacak Şehir ve Bölge Planlama Bölümleri İçin Gerekli Asgari Ölçütler" isimli bu rapor ile lisans seviyesinde eğitim verecek bir ŞBP bölümünün varlığı için gerekli asgari ölçütleri belirlemek; bu ölçütlere dayanarak mevcut planlama bölümlerinin durumunu değerlendiren tespitler yapmak; yeni veya mevcut ŞBP bölümlerinin nasıl geliştirilmesi gerektiğine dair yol göstermek amaçlanmıştır (TUPOB, 2011: 2).

Bir ortak akıl çalışması olan bu raporda, öncelikle dünyada ve ülkemizdeki ŞBP lisans eğitiminin mühendislik, tıp, sosyal bilimler ve diğer birçok meslek alanından farklılaşan özellikleri olduğuna ve dolayısıyla öğretim kadrosu, fiziki altyapı ve donanım açısından farklılaşan gereksinimleri bulunduğuna dikkat çekilmiştir. TUPOB'a göre, planlama eğitiminin merkezinde bulunan ve birçok disiplinden farklılaşan temel özelliği, "stüdyo eğitimi" veya "stüdyo" diye adlandırılan ve mimarlık, endüstri ürünleri tasarımı gibi meslek alanlarının da merkezinde olan tasarım, plan-proje geliştirme yani uygulama ağırlıklı bir eğitimin olmasıdır. Şehir planlama stüdyo dersleri, her yarıyılda bir tane olmak üzere toplam sekiz adettir ve bölüm ders programının en çok ders saati olan uygulama-teorik dersleridir. Dolayısıyla, stüdyo dersleri ve proje çalışmaları planlama eğitiminin omurgasını oluşturmaktadır. Ancak bir stüdyoda yürütülen proje çalışmalarının takibi, örneğin, bir kimya laboratuvarındaki öğrenci çalışmalarının takibinden farklıdır. Bir planlama stüdyosunda sorumlu öğretim elemanı, öğrenci ve/veya öğrenci çalışma gruplarıyla yüz yüze görüşerek proje ve çalışmalarına yorum yapar, eleştirilerde bulunur ve o projenin nasıl geliştirilebileceğine dair yol gösterir. Usta-çırak ilişkisini gerektiren bu durum, bir öğretim elemanının bir ders saatinde ilgilenebileceği proje / öğrenci sayısını kısıtlar. Dolayısıyla, stüdyo eğitiminin kalitesi, bir öğretim elemanının bir ders saatinde ilgilenebileceği öğrenci sayısının belli seviyelerde tutulmasına bağlıdır. Bu nedenle, ŞBP bölümlerinin öğrenci kontenjanlarının belirlenmesinde diğer alanlar için konulan ölçütlerin kullanılması uygun değildir. Bir planlama bölümünde öğrenci kontenjanı sayısını belirleyen şey, o bölümün ögretim üyesi sayısı olmalıdır (TUPOB, 2011: 10-24).

Raporda, usta-çırak ilişkisine dayanan stüdyo eğitiminin başarısında kontenjan sayıları ve öğretim üyesi sayıları arasındaki ilişki açıklanırken, bu çerçevede dünyadaki başarılı planlama okullarından örnekler verilmiştir. Bu örneklerden bir kısmı ABD'de MIT, Harvard Üniversitesi, Kaliforniya-Berkeley Üniversitesi; Avrupa'da Newcastle Upon Tyne Üniversitesi, Sheffield Üniversitesi ve Cardiff Üniversitesidir (TUPOB, 2011: EK1). Sunulan örneklerden çıkarılan dersler 1şı̆̆ında, bir planlama bölümünde kadro sayısının yeterli olmasının ve deneyimli kadroların görev yapmasının planlama eğitiminde kaliteyi artırdığı belirtilmiştir.

TUPOB raporunda, planlama eğitiminin özel bir eğitim alanı olduğu ve bu eğitimin kendine has temel özellikleri ortaya konulduktan sonra, yurtdışı örneklerinin incelenmesiyle ve TUPOB üyesi ŞBP bölümlerinin görüşlerinin değerlendirilmesiyle oluşturulan azami ve

\footnotetext{
5 TUPOB, 2004 yılında ŞBP bölümlerinin bir araya gelerek kurduğu bir birliktir. Birliğin kuruluş amac1, Türkiye'deki ŞBP bölümlerinin ortak sorunlarını ele almak yanı sıra eğitim ve araştırmaya yönelik işbirliklerini geliştirmektir. Birlik hakkında daha ayrıntılı bilgi için bkz. (TUPOB, 2011).
} 
asgari ölçütler açıklanmıştır ${ }^{6}$. Rapora göre, kontenjanlar ve öğretim kadrosu büyüklüğü ile ilgili olarak, bir ŞBP bölümünde öğrenci kontenjanı azami 25-30 veya 30-40 öğrenci olmalı, bir öğretim üyesi başına düşen birinci sene öğrenci sayısı azami 2 olmalıdır. 2/1 oranına göre (öğrenci kontenjan sayıs1 / öğretim üyesi sayıs1), bir ŞBP bölümünde lisans eğitimine başlanabilmesi için gerekli öğretim üyesi sayısı asgari 12 olmalıdır (TUPOB, 2011: 13-25).

Raporda ŞBP bölümleri için gerekli ölçütler açıklandıktan sonra, planlama okullarının mevcut durumu bu ölçütlere göre değerlendirilmiş ve bazı öneriler geliştirilmiştir. ${ }^{7}$ TUPOB'un değerlendirmelerine göre, lisans eğitimi veren ŞBP bölümlerinin öğretim kadrosu, fiziki altyapısı ve donanımları nitelikli ve etkin bir planlama eğitimi için yetersizdir. Özellikle 1990 yılı sonrasında kurulan planlama bölümleri; nitelikli ve etkin bir planlama eğitimi verebilmeleri için henüz olması gereken asgari kadroya ulaşamamışlardır. Mevcut ŞBP bölümlerindeki eğitim kalitesini yükseltmek için öğretim kadrosu üzerindeki öğrenci ve ders yüklerinin azaltılması gerekmektedir. Bu nedenle, öncelikle halen lisans eğitimi veren ŞBP bölümlerinin öğretim kadroları, fiziki altyapıları ve donanımları iyileştirilmelidir. Mevcut durumu iyileştirmeden yeni planlama bölümleri açmak planlama eğitimi için ayrılan kaynakların parçalanmasına ve eğitim kalitesinin daha da düşmesine yol açacaktır (TUPOB, 2011: 25).

Ancak, TUPOB'un yapmış olduğu bu değerlendirmelere rağmen, 2011 sonrasında birçok yeni ŞBP bölümü kurulmuş olup bir kısmı lisans eğitimine başlamış, diğer bir kısmı ise eğitime başlama hazırlığ içindedir. 2016-2017 öğretim y1lı itibariyle, Türkiye'de 50'nin üzerinde üniversitede ŞBP bölümü yer almakta ve bu bölümlerin 21'inde lisans düzeyinde planlama eğitimi verilmektedir. ${ }^{8}$

TUPOB ölçütleri yeni ŞBP bölümlerinin yapılandırılmasında etkili olabilmiş midir? Hali hazırda, lisans düzeyinde eğitim veren ŞBP bölümleri, TUPOB'un belirlemiş olduğu ölçütleri ne düzeyde karşılamaktadır? Bu sorulara ilişkin güncel ve kısmi cevaplar 8. Türkiye Şehircilik Kongresi'nde sunulan bazı bildirilerde ve Kongre'nin TUPOB oturumundaki

${ }^{6}$ TUPOB raporunda lisans düzeyinde ŞBP eğitimi için gerekli asgari ve azami ölçütler 3 ana başlık altında sunulmaktadır: Kontenjanlar ve ögretim kadrosu büyüklüğ̈̈; fiziki altyapı ve donanım; coğrafi ve finansal erişilebilirlik (TUPOB, 2011: 10-16).

7 TUPOB raporunun yazıldığı tarihte lisans düzeyinde eğitim veren 12 adet ŞBP bölümü olup, 8 adet ŞBP bölümü henüz eğitime başlamamıştır. ŞBP bölümleri, söz konusu raporda iki grup olarak tanımlanmıştır: "İlk grup" olarak tanımlanan ŞBP bölümleri 1961-1984 arasında kurulan planlama okullarıdır. "İkinci grup" olarak tanımlanan ŞBP bölümleri 1990 sonrasında kurulan planlama okulları olup (s: 4), bu bölümler lisans eğitimi verenler ve henüz lisans eğitimi vermeyenler şeklinde iki alt gruba ayrılmıştır. Rapora göre; lisans düzeyinde eğitim veren 12 adet ŞBP bölümünde ortalama öğretim elemanı sayıs1 14'dür. İlk kurulan planlama bölümleri ögretim kadrosu açısından belli bir olgunluğa erişmiştir. Bu grupta ortalama öğretim kadrosu sayısı 21'dir. Ancak, daha sonra kurulan planlama bölümleri bu seviyenin çok altında olup, bu bölümlerdeki ortalama öğretim kadrosu sayıs1 8'dir. Dolayısıyla, 1990 sonrasında kurulan ve lisans düzeyinde planlama eğitimi veren bölümlerin öğretim kadro sayısının arttırılması gerekmektedir. Ortalama öğretim elemanı sayısı, henüz lisans eğitimine başlamamış olan ŞBP bölümlerinde ise çok düşük olup, bu grupta ortalama öğretim kadrosu sayısı 3 'dür. Ayrıca, 2008 sonrasında birçok bölümde yaşanan kontenjan artışı nedeniyle, öğretim üyesi başına düşen ortalama öğrenci sayısı belirlenen üst eşiği aşmıştır. Sonuç olarak, akademik kadro yetersizliği ŞBP bölümlerinin en önemli sorunlarından biridir (TUPOB, 2011, s: 16-24).

8 2016-2017 öğretim yılı itibariyle, lisans eğitimine başlamış ve başlamamış bütün ŞBP bölümlerinin listesi Cömertler'in “55. Yılında Türkiye'de Şehir ve Bölge Planlama Bölümleri” isimli bildirisinde yer almaktadır (8. Türkiye Şehircilik Kongresi, 6-7-8 Kasım 2016, Ankara). 
sunum ve tartışmalarda verilmiştir. Örneğin, Cömertler (2016) lisans düzeyinde eğitim veren planlama okullarının genel ve güncel bir resmini ortaya koymuştur. Dursun (2016) Atatürk Üniversitesi ŞBP bölümünü vaka çalışması olarak sunmuştur. Dursun'un (2016) ve Cömertler'in (2016) ortaya koydukları bulgular, resmin genelini yanı sira Atatürk Üniversitesi ŞBP bölümü özelinde bir örneğini göstermesi ve güncel olması bakımından faydalıdır. Ancak bu bulgular, yukarıdaki sorulara verilen kısmi cevaplardır. Sonuç olarak, planlama okullarının tamamını kapsayan ve onları gruplar halinde karşılaştırmalı olarak inceleyen, böylece planlama okullarının yapılandırılmasında TUPOB ölçütlerinin etkinliğini ve planlama okullarının TUPOB ölçütlerini karşılama düzeyini niceliksel analizlerle sorgulayan bir çalışma henüz literatürde yer almamıştır.

Böyle bir eksiklikten hareketle, bu makalede, 2016-2017 öğretim yılı itibariyle Türkiye'de planlama eğitiminin lisans düzeyinde verildiği ŞBP bölümlerinin öğretim kadrolarının TUPOB ölçütlerine göre yeterliliğini gruplar bazında karşılaştırmalı olarak niceliksel analizler ile ortaya koymak ve TUPOB ölçütlerinin ŞBP bölümlerinin yapılandırılmasında etkili olup olmadığını anlamak amaçlanmıştır.

$\mathrm{Bu}$ amaç doğrultusunda, makale 4 kısımdan oluşturulmuştur. Birinci kısımda problem tanımlaması, çalışmanın amacı ve organizasyonu açıklanmıştır. Materyal ve yöntem başlığ altında, öncelikle, araştırmanın öznesini oluşturan ŞBP bölümleri hakkında kısa bir bilgi verilmiştir ${ }^{9}$. Devamında, çalışmada kullanılan değişkenler, bu değişkenlere ilişkin verilerin toplanması ve düzenlenmesi, nihayetinde de veri analiz yöntemi açıklanmıştır. Üçüncü kısımda, planlama eğitiminin lisans düzeyinde verildiği ŞBP bölümlerinin öğretim kadrolarına ilişkin niceliksel analiz bulguları önce gruplar bazında sunulmuş, ardından gruplar arasında karşılaştırmalar yapılmıştır. Son kısımda bulguların kısa bir özeti ve değerlendirmesi yapılmış, ardından politika ve araştırma önerileri sunulmuştur.

\section{Materyal ve Yöntem}

Araştırmanın öznesini, hali hazırda lisans düzeyinde öğrenci kabulü olan ve eğitim faaliyetlerini sürdüren 21 adet ŞBP bölümü oluşturmakta olup, araştırma kapsamında bu bölümler birinci, ikinci ve üçüncü grup ŞBP bölümleri olarak üç grupta ele alınmıştır. Birinci ve ikinci grup ŞBP bölümleri tanımlaması TUPOB 2011 raporunda yer almıştır. Üçüncü grup ŞBP bölümleri tanımlaması bu çalışmada yapılmıştır.

Birinci grup ŞBP bölümleri 1984'e kadar kurulan planlama okullarıdır. Bu bölümler TUPOB 2011 raporunda da ilk grup olarak tanımlanmıştır. Bu grupta 6 adet ŞBP bölümü olup, bunların tamamı devlet üniversitelerinde yer almaktadır. Dördünün eğitim dili Türkçe, Orta Doğu Teknik Üniversitesi ŞBP bölümünün eğitim dili İngilizcedir. İstanbul Teknik Üniversitesi ŞBP bölümünün ise hem İngilizce hem de Türkçe olmak üzere iki programı vardır. Türkiye'nin üç büyük kentinde yer alan bu ilk ŞBP bölümlerinin tamamında lisans, yüksek lisans ve doktora düzeyinde planlama eğitimi verilmektedir. Bu gruptaki ŞBP bölümleri (alfabetik sırayla) şu üniversitelerde yer almaktadır: Dokuz Eylül Üniversitesi (DEÜ), Gazi Üniversitesi (GÜ), İstanbul Teknik Üniversitesi (İTÜ), Mimar Sinan Güzel

\footnotetext{
${ }^{9} \mathrm{Bu}$ bilgilendirme bölümlerin web sitelerinden elde edilen bilgiler ışığında yapılmıştır. Analizlere dahil olan ŞBP bölümlerinin web sitelerinin URL adresleri kaynakçada yer almaktadır.
} 
Sanatlar Üniversitesi (MSGSÜ), Orta Doğu Teknik Üniversitesi (ODTÜ), Yıldız Teknik Üniversitesi (YTÜ).

Araştırmada, 1994-2011 y1lları arasında lisans eğitimine başlayan 7 adet planlama okulu ikinci grup ŞBP bölümleri olarak tanımlanmıștır. Bu bölümler TUPOB 2011 raporunda ikinci grup olarak tanımlanan ŞBP bölümlerinin bir kısmını oluşturmaktadır. Bu gruptaki bölümlerin tamamı devlet üniversitelerinde yer almaktadır. Bir kısmı büyük şehirlerde bir kısmı ise küçük kentlerdedir. İkinci gruptaki ŞBP bölümlerinin eğitim dili İzmir Yüksek Teknoloji Enstitüsü ve Mersin Üniversitesi ŞBP bölümleri hariç Türkçedir. İlk gruptan farklı olarak, bu grupta lisans düzeyinde planlama eğitimi öne çıkmaktadır ${ }^{10}$. Bu gruptaki ŞBP bölümleri şu üniversitelerde yer almaktadır: Bozok Üniversitesi (BÜ), Erciyes Üniversitesi (EÜ), İzmir Yüksek Teknoloji Enstitüsü (IYTTE), Karadeniz Teknik Üniversitesi (KTÜ), Mersin Üniversitesi (MÜ), Selçuk Üniversitesi (SÜ), Süleyman Demirel Üniversitesi (SDÜ).

TUPOB'un 2011'de bir dizi ölçüt geliștirmesinden sonra lisans düzeyinde eğitime bașlayan 8 adet planlama okulu, bu çalışmada üçüncü grup ŞBP bölümleri olarak ele alınmıştır ${ }^{11}$. Bu gruptaki ŞBP bölümleri diğer gruplardan farklı olarak, hem vakıf hem de devlet üniversiteleri bünyesinde yer almaktadır. Devlet üniversitelerindeki ŞBP bölümlerinin eğitim dili Türkçe, vakıf üniversiteleri bünyesinde kurulan ŞBP bölümlerinin eğitim dili ise İngilizcedir. İkinci gruptakilere benzer bir şekilde, üçüncü grup ŞBP bölümlerinin de bir kısmı büyük șehirlerde bir kısmı ise küçük kentlerde kurulmuștur ve bu grupta da lisans düzeyinde planlama eğitimi ön plana çıkmaktadır. Üçüncü gruptaki ŞBP bölümleri şu üniversitelerde yer almaktadır: Amasya Üniversitesi (AÜ), Atatürk Üniversitesi (AÜ2), Bursa Teknik Üniversitesi (BTÜ), Çankaya Üniversitesi - vakıf (ÇÜ), Kırklareli Üniversitesi (KÜ), Necmettin Erbakan Üniversitesi (NEÜ), Pamukkale Üniversitesi (PÜ), TED Üniversitesi - vakıf (TEDÜ).

2016-2017 öğretim yılında lisans düzeyinde öğrenci kabulü olan ve eğitim faaliyetlerini sürdüren ŞBP bölümlerini, öğretim kadrosu yeterliği bağlamında analiz eden bu araştırmada şu değişkenler kullanılmıştır: yardımcı doçent sayısı, doçent sayısı, profesör sayısı, toplam öğretim üyesi sayıs1 ${ }^{12}$, bir öğretim üyesi başına düşen birinci sene öğrenci sayıs1 ${ }^{13}$.

Değişkenlere ilişkin veriler, ÖSYM'nin, YÖK'ün ve ŞBP bölümlerinin web sitelerinden araştırılmış; ÖSYM'nin hazırladığı 2016-ÖSYS Yükseköğretim Programları ve

\footnotetext{
10 İkinci grupta yer alan planlama okulları içinde lisansüstü eğitim vurgusu ile öne çıkan İzmir Yüksek Teknoloji Enstitüsü ŞBP bölümünde, Şehir Planlama doktora programına hali hazırda yeni öğrenci kabulü yapılamamaktadır.

11 Daha önce üçüncü grupta yer alan 2 tane ŞBP bölümü 2016-2017 öğretim y1lında öğrenci almamıştır (Cumhuriyet Üniversitesi ve Toros Üniversitesi ŞBP Bölümleri). Hali hazırda yeni öğrenci alımı olmayan bu planlama okulları araştırmanın kapsamı içine alınmamış ve analizlere dahil edilmemiştir.

12 Analizlerde kullanılan öğretim üyesi sayıları ŞBP bölümlerinde kadrolu olarak çalışan öğretim üyelerine ilişkindir, misafir öğretim üyeleri ve araştırma görevlileri bu sayılara dahil değildir.

13 Bir öğretim üyesi başına düşen birinci sene öğrencisi değişkenine ilişkin verilerin temininde bölümlerin kontenjan sayıları da incelenmiştir. 2016-ÖSYS Yükseköğretim Programları ve Kontenjanları Kılavuzu - Tablo 4'de açıklanan genel kontenjan ve özel kontenjanların toplamı bölümün kontenjan verisi olarak alınmıștır. Ayrıca, farklı programlara sahip ŞBP bölümleri için, programların toplam kontenjanı (burslu + burssuz, İngilizce + Türkçe) bölümün kontenjan verisi olarak alınmıştır. Yatay-dikey geçiş ve yabancı uyruklu öğrenci kotaları kontenjan sayısına dahil değildir.
} 
Kontenjanlar1 K1lavuzu - Tablo 4'de yer alan veriler, güncel ve resmi olduğu, dolayısıyla geçerliliği daha yüksek olduğu kabulü ile analizlerde kullanılmak üzere esas alınmıştır ${ }^{14}$. Verilerin düzenlenmesi sürecinde, ilk olarak 2016-ÖSYS Yükseköğretim Programları ve Kontenjanları Kılavuzu - Tablo 4'de yer alan ŞBP bölümleri seçilerek, 2016 ŞBP Bölümleri ve Kontenjanları tablosu oluşturulmuştur. Ardından, toplam öğretim üyesi sayısı (yardımcı doçent + doçent + profesör) ve bir öğretim üyesi başına düşen birinci sene öğrenci sayısı (kontenjan / toplam öğretim üyesi) hesaplamaları yapılmıştır. Son aşamada, veriler gruplar halinde ayrı ayrı tablolar olarak düzenlenmiştir. Bu tablolarda ŞBP bölümleri üniversite isimlerine göre alfabetik olarak sıralanmıştır.

Araştırmada, değişkenlere temel istatistik analizler uygulanmış olup, bu çerçevede toplam, ortalama, en yüksek ve en düşük değerler önce gruplar bazında, sonra gruplar arasında karşılaştırmalı olarak incelenmiştir. Ayrıca, grup içi ve gruplar arası değerlendirmelerde frekans analizleri de kullanılmıştır.

\section{Bulgular}

\subsection{Birinci Grup ŞBP Bölümleri}

Altı tane ŞBP bölümünün yer aldığı birinci grupta toplam öğretim üyesi sayısı 139 'dur. $\mathrm{Bu}$ gruptaki ŞBP bölümlerinde ortalama 23 öğretim üyesi bulunmakta olup, bu ortalama TUPOB'un belirlemiş olduğu asgari öğretim üyesi sayısı standardının - en az 12 öğretim üyesi - üzerindedir. Bu gruptaki en geniş öğretim üyesi kadrosuna 31 öğretim üyesi ile İTÜ ŞBP bölümü sahip iken, en az sayıda kadrolu öğretim üyesi ise ODTÜ ŞBP bölümünde bulunmaktadir.

Çizelge 1'de yer alan ŞBP bölümleri tek tek incelendiğinde, birinci gruptaki bütün planlama okullarının TUPOB'un belirlemiş olduğu asgari öğretim üyesi standardını karşıladığ görülmektedir. Şüphesiz, bu olumlu bir durumdur. Ancak TUPOB'un belirlemiş olduğu standardın, yalnızca lisans düzeyinde planlama eğitimi için gerekli asgari öğretim üyesi sayısına işaret ettiği dikkate alındığında; lisans yanı sıra yüksek lisans ve doktora düzeyinde planlama eğitimi veren, ayrıca kongre, sempozyum, çalıştay, sergi vb. çeşitli bilimsel ve mesleki etkinliklere öncülük eden, ev sahipliği yapan, destek veren bu ŞBP bölümlerinin öğretim üyesi sayısı bağlamında dünyadaki emsallerine göre yeterli olmadığı söylenebilir.

\footnotetext{
${ }^{14}$ 2016-ÖSYS Yükseköğretim Programları ve Kontenjanları Kılavuzu - Tablo 4'de yer alan veriler 2016 y1lı yaz dönemine aittir.
} 
Çizelge 1: Birinci grup ŞBP bölümleri öğretim üyesi sayıları

\begin{tabular}{|c|c|c|c|c|}
\hline ÜNIVERSITE & PROFESÖR & DOÇENT & $\begin{array}{l}\text { YARDIMCI } \\
\text { DOÇENT }\end{array}$ & $\begin{array}{l}\text { TOPLAM } \\
\text { ÖĞRETIM } \\
\text { ÜYESİ }\end{array}$ \\
\hline DOKUZ EYLÜL ÜNIVERSİTESİ (DEÜ) & 5 & 2 & 12 & 19 \\
\hline GAZİ ÜNIVERSİTESİ (GÜ) & 3 & 13 & 5 & 21 \\
\hline İSTANBUL TEKNIK ÜNIVERSITTESİ (İTÜ) & 15 & 9 & 7 & 31 \\
\hline MIMMAR SINAN ÜNIVERSİTESİ (MSÜ) & 5 & 8 & 13 & 26 \\
\hline $\begin{array}{l}\text { ORTA DOĞU TEKNİK ÜNIVERSITESİ } \\
\text { (ODTÜ) }\end{array}$ & 9 & 5 & 4 & 18 \\
\hline YILDIZ TEKNIK ÜNIVERSITESİ (YTÜ) & 6 & 9 & 9 & 24 \\
\hline BİRINCİ GRUP ORTALAMA & 7,2 & 7,7 & 8,3 & 23,2 \\
\hline BİRINCİ GRUP TOPLAM & 43 & 46 & 50 & 139 \\
\hline
\end{tabular}

Öğretim kadrosu yeterliliği, akademik unvan çeşitliliği bağlamında incelendiğinde (Şekil 1), öğretim üyelerinin akademik unvanlara göre dağılımının grup genelinde birbirine yakın oranlarda olduğu görülmektedir. Birinci gruptaki öğretim üyelerinin \% 31'i profesör, \% 33'ü doçent, \% 36'sı yardımcı doçenttir. Bu çeşitlilik olumludur. Ancak, öğretim üyelerinin akademik unvanlara göre dağılımı bölümler bazında tek tek incelendiğinde (Çizelge 1), genelden farklı kompozisyonlarla karşılaşılmaktadır. Bu grupta yer alan planlama okulları içinde YTÜ ŞBP bölümü, akademik unvan çeşitliliği bağlamında en dengeli dağılıma sahip öğretim kadrosunun bulunduğu planlama okulu olarak öne çıkmaktadır.

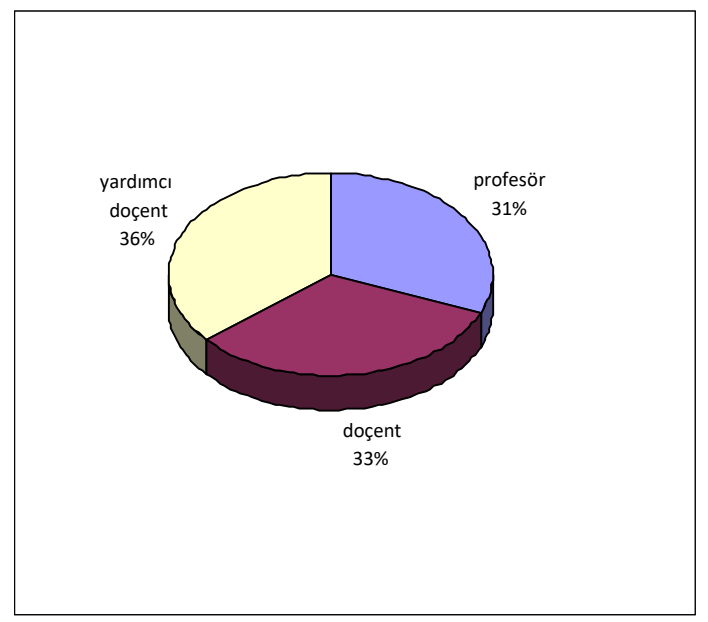

Şekil 1: Birinci grup ŞBP bölümlerinde öğretim üyelerinin akademik unvanlara göre dağılımı 
Birinci grupta toplam profesör sayıs1 43 olup, her planlama okulunda ortalama 7,2 profesör vardır. Bu gruptaki profesörlerin yaklaşık 1/3'ü (15 profesör) tek bir bölümde (İTÜ ŞBP) yer alırken, bir başka ŞBP bölümünde (GÜ ŞBP) yaklaşık olarak 1/15'i (3 profesör) bulunmaktadır. Gruptaki diğer ŞBP bölümlerinde ise profesör sayıları ortalama değere yakındır. Dolayısıyla, uç değer gösteren 2 ŞBP bölümü dışında, birinci grupta profesörlerin dağılımının dengeli olduğu söylenebilir. Çizelge 1 incelendiğinde, doçent sayıları ve dağılımlarının profesörlerinkine benzer olduğu görülmektedir. Bu grupta, toplam doçent sayıs1 46 olup, bir ŞBP bölümünde ortalama 7,7 doçent görev yapmaktadır. En çok sayıda doçent (bu gruptaki doçentlerin yaklaşık 1/3'ü) GÜ ŞBP bölümünde, en az sayıda doçent ise (bu gruptaki doçentlerin yaklaşık 1/21'i) DEÜ ŞBP bölümündedir. Birinci grupta yer alan ŞBP bölümlerindeki toplam yardımcı doçent sayısı 50'dir. Ortalama olarak her bir ŞBP bölümünde 8,3 yardımcı doçent bulunmaktadır. En çok sayıda yardımcı doçent MSGSÜ ŞBP bölümünde, en az sayıda yardımcı doçent ise ODTÜ ŞBP bölümündedir.

Çizelge 2: Birinci grup ŞBP bölümleri kontenjan/öğretim üyesi oranları

\begin{tabular}{|l|l|l|l|}
\hline ÜNIVERSITE & KONTENJAN & $\begin{array}{l}\text { TOPLAM } \\
\text { ÖĞRETIM } \\
\text { ÜYESI }\end{array}$ & $\begin{array}{l}\text { KONTENJAN / } \\
\text { ÖGRETIM ÜYESI } \\
\text { ORANI }\end{array}$ \\
\hline DOKUZ EYLÜL ÜNIVERSITTESI (DEÜ) & 93 & 19 & 4,9 \\
\hline GAZİ ÜNIVERSİTESİ (GÜ) & 68 & 21 & 3,2 \\
\hline İSTANBUL TEKNIK ÜNIVERSITESİ (ITÜ) & 98 & 31 & 3,2 \\
\hline MIMAR SINAN ÜNIVERSITESİ (MSÜ) & 67 & 26 & 2,6 \\
\hline ORTA DOĞU TEKNIK ÜNIVERSITESI & 62 & 18 & 3,4 \\
\hline YILDIZ TEKNIK ÜNIVERSITESİ (YTÜ) & 62 & 24 & 2,6 \\
\hline BİRINCI GRUP ORTALAMA & $\mathbf{7 5}$ & $\mathbf{2 3 , 2}$ & $\mathbf{3 , 3}$ \\
\hline
\end{tabular}

Öğretim kadrosu yeterliliği, bir öğretim üyesi başına düşen azami birinci sene öğrencisi sayısı bağlamında incelendiğinde (Çizelge 2), birinci gruptaki bölümlerde kontenjan/öğretim üyesi oranı ortalamasının, bir öğretim üyesi başına 3,3 birinci sene öğrencisi ile TUPOB'un belirlemiş olduğu azami standardın - bir öğretim üyesi başına 2 birinci sene öğrencisi üzerinde olduğu görülmektedir. Birinci grupta en yüksek kontenjan/öğretim üyesi oranı, bir öğretim üyesi başına 4,9 birinci sene öğrencisi ile DEÜ ŞBP bölümünde iken, bir öğretim üyesi başına 2,6 birinci sene öğrencisi ile en düşük kontenjan/öğretim üyesi oranı MSGSÜ ve YTÜ ŞBP bölümlerinde tespit edilmiştir.

Çizelge 2'de yer alan ŞBP bölümleri tek tek incelendiğinde, birinci gruptaki ŞBP bölümlerinin hiç birisinin TUPOB'un belirlemiş olduğu azami kontenjan/öğretim üyesi standardını sağlayamadığı görülmektedir. Bu durumun en önemli sebebi kontenjan sayılarının çok yüksek olmasıdır. Bu gruptaki tüm bölümlerde kontenjan sayıları TUPOB'un belirlemiş olduğu azami kontenjan standardının - 40 öğrenci - üzerindedir. 


\section{2. İkinci Grup ŞBP Bölümleri}

İkinci grupta yer alan 7 adet ŞBP bölümündeki toplam öğretim üyesi sayıs1 54 olup, ortalama olarak bölüm başına 7,7 öğretim üyesi düşmektedir (Çizelge 3). Bu grupta en geniş öğretim kadrosu 13 öğretim üyesi ile IYTE ŞBP bölümünde yer alırken, bir doçent ve iki yardımcı doçent ile en az sayıda öğretim üyesi BÜ ŞBP bölümündedir. Bu gruptaki ŞBP bölümlerinin yalnızca bir tanesi (IYTE ŞBP Bölümü) TUPOB'un belirlemiş olduğu asgari öğretim üyesi standardını karşılamaktadır. Dolayısıyla, TUPOB'un 2011 yılında dikkat çekmiş olduğu öğretim kadrosu yetersizliği sorunu ikinci grup ŞBP bölümlerinde hala aş1lamamıştır.

\begin{tabular}{|c|c|c|c|c|}
\hline ÜNIVERSITE & PROFESÖR & DOÇENT & $\begin{array}{l}\text { YARDIMCI } \\
\text { DOÇENT }\end{array}$ & $\begin{array}{l}\text { TOPLAM } \\
\text { ÖĞRETİM } \\
\text { ÜYESİ }\end{array}$ \\
\hline BOZOK ÜNIVERSITESİ (BÜ) & 0 & 1 & 2 & 3 \\
\hline ERCIYES ÜNIVERSITTESİ (EÜ) & 0 & 0 & 7 & 7 \\
\hline İZMİR YÜKSEK TEKNOLOJI ENST. (IYTE) & 0 & 5 & 8 & 13 \\
\hline KARADENIZ TEKNIK ÜNIVERSITESİ (KTÜ) & 0 & 3 & 6 & 9 \\
\hline MERSIN ÜNIVERSITTESI (MÜ) & 0 & 2 & 6 & 8 \\
\hline SELÇUK ÜNIVERSITESİ (SÜ) & 0 & 2 & 6 & 8 \\
\hline SÜLEYMAN DEMIREL ÜNIVERSITESİ (SDÜ) & 3 & 2 & 1 & 6 \\
\hline İKINCI GRUP ORTALAMA & 0,4 & 2,1 & 5,1 & $\mathbf{7 , 7}$ \\
\hline İKINCI GRUP TOPLAM & 3 & 15 & 36 & 54 \\
\hline
\end{tabular}

Öğretim üyelerinin akademik unvanlara göre dağılımı incelendiğinde, bu gruptaki ŞBP bölümlerinin öğretim kadrolarını önemli ölçüde yardımcı doçentlerin oluşturduğu görülmektedir (Şekil 2). İkinci gruptaki öğretim üyelerinin \% 5'i profesör, \% 28'ü doçent, \% 67'si ise yardımcı doçenttir. Bu bulgular, ikinci gruptaki ŞBP bölümlerinde öğretim kadrolarının akademik unvanlara göre dengeli çeşitlilik sunmadığını göstermektedir. 


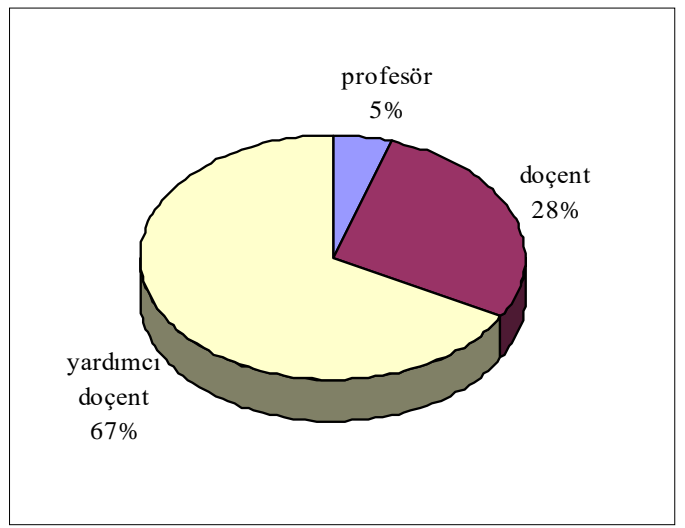

Şekil 2: İkinci grup ŞBP bölümlerinde öğretim üyelerinin akademik unvanlara göre dağılımı

İkinci gruptaki ŞBP bölümleri "profesörsüz planlama okulları" olarak tanımlanabilir. Çünkü bir tanesi hariç bu gruptaki ŞBP bölümlerinin hiç birinde profesör bulunmamaktadır. SDÜ ŞBP bölümü 3 profesör ile bünyesinde profesör bulunduran tek planlama okuludur. Bu bulgu istatistiksel açıdan anomali olarak nitelendirilebilecek bir durumu göstermektedir. Zira gruptaki bölümlerin bir tanesi en fazla (3), diğerleri ise en az değere (0) sahiptir. Diğer bir ifadeyle, gruptaki tüm bölümler uç değer özelliği göstermektedir ki, bu istatistiksel açıdan normal bir durum değildir. Burada temel sorun "yokluk"tur, ikincil sorun ise "dağılımdaki dengesizlik"tir. Çizelge 3 incelendiğinde, bu gruptaki doçentlerin varllğg 1 ve dağ 1 lımının profesörlere kıyasla görece dengeli olduğu söylenebilir, ancak bir "azlık" sorunu vardır. İkinci gruptaki ŞBP bölümleri içinde toplam doçent sayıs1 15 olup, bir ŞBP bölümünde ortalama 2,1 doçent görev yapmaktadır. En çok sayıda doçent ( 5 tane) IYTTE ŞBP bölümünde yer alırken, EÜ ŞBP bölümünde ise hiç doçent yoktur. Bu grupta toplam yardımcı doçent sayısı 36'dır ve bir ŞBP bölümünde ortalama 5,1 yardımcı doçent bulunmaktadır. En çok sayıda yardımcı doçent ( 8 tane) IYTE ŞBP bölümünde, en az sayıda yardımcı doçent ise (1 tane) SDÜ ŞBP bölümünde çalışmaktadır. İkinci gruptaki ŞBP bölümlerinde, yardımcı doçentlerin grup içindeki dağılımı - SDÜ ve BÜ ŞBP bölümleri hariç - oldukça dengelidir.

Çizelge 4: İkinci grup ŞBP bölümleri kontenjan/öğretim üyesi oranları

\begin{tabular}{|l|l|l|l|}
\hline & KONTENJAN & $\begin{array}{l}\text { TOPLAM } \\
\text { ÖGRETIM } \\
\text { ÜYESİ }\end{array}$ & $\begin{array}{l}\text { KONTENJAN / } \\
\text { ÖGRETIM } \\
\text { ÜYESİ ORANI }\end{array}$ \\
\hline BOZOK ÜNIVERSITESİ (BÜ) & 62 & 3 & 20,7 \\
\hline ERCIYES ÜNIVERSITESİ (EÜ) & 72 & 7 & 10,3 \\
\hline İZMIR YÜKSEK TEKNOLOJI ENSTITÜSÜ & 52 & 13 & 4 \\
\hline KARADENIZ TEKNIK ÜNIVERSİTESI (KTÜ) & 62 & 9 & 6,9 \\
\hline MERSIN ÜNIVERSITESİ (MÜ) & 41 & 8 & 5,1 \\
\hline SELÇUK ÜNIVERSITESİ (SÜ) & 72 & 8 & 9 \\
\hline SÜLEYMAN DEMIREL ÜNIVERSITESİ (SDÜ) & 52 & 6 & 8,7 \\
\hline İKINCİ GRUP ORTALAMA & $\mathbf{5 9}$ & $\mathbf{7 , 7}$ & $\mathbf{7 , 6}$ \\
\hline
\end{tabular}


Öğretim kadrosu yeterliliği öğrenci popülasyonu ile birlikte analiz edildiğinde, ikinci gruptaki ŞBP bölümlerinde kontenjan/öğretim üyesi oranı ortalamasının, bir öğretim üyesi başına 7,6 birinci sene öğrencisi ile TUPOB'un belirlemiş olduğu azami standardın çok üstünde olduğu saptanmıştır (Çizelge 4). Bu grupta en yüksek kontenjan/öğretim üyesi oranı, bir öğretim üyesi başına 20,7 birinci sene öğrencisi ile BÜ ŞBP bölümünde iken, bir öğretim üyesi başına 4 birinci sene öğrencisi ile en düşük kontenjan/öğretim üyesi oranı IYTE ŞBP bölümünde tespit edilmiştir. Çizelge 4 incelendiğinde, ikinci gruptaki ŞBP bölümlerinin hiç birisinin TUPOB'un belirlemiş olduğu azami kontenjan/öğretim üyesi standardını sağlayamadığı görülmektedir. Bu durumun öğretim üyesi "azlığı" ve öğrenci "çokluğu" olmak üzere iki temel sebebi vardır. İkinci grup ŞBP bölümlerinde, öğretim üyesi sayısı asgari standardın altında, öğrenci kontenjanı sayısı ise azami standardın çok üzerindedir.

\section{3. Üçüncü Grup ŞBP Bölümleri}

Sekiz tane ŞBP bölümünün yer aldığı bu grupta toplam öğretim üyesi sayısı 31 ' dir $^{15}$. Üçüncü grupta, bir ŞBP bölümü başına ortalama 3,9 öğretim üyesi düşmekte olup, bu sayı TUPOB'un belirlemiş olduğu asgari öğretim üyesi standardının yaklaşık 1/3'üne tekabül etmektedir. Üçüncü grupta en çok öğretim üyesi 5 akademisyen ile BTÜ ve NEÜ ŞBP bölümlerinde, en az ögretim üyesi ise 3 akademisyen ile PÜ, AÜ ve TEDÜ ŞBP bölümlerinde bulunmaktadır. Çizelge 5'den görüldüğ̈̈ üzere, TUPOB'un 2011 yılında ortaya koyduğu asgari öğretim üyesi standardı bu tarihten sonra lisans eğitimine başlayan ŞBP bölümlerinin hiçbirinde sağlanamamıştır.

Çizelge 5: Üçüncü grup ŞBP bölümleri öğretim üyesi sayıları

\begin{tabular}{|l|l|l|l|l|}
\hline ÜNIVERSITE & PROFESÖR & DOÇENT & $\begin{array}{l}\text { YARDIMCI } \\
\text { DOÇENT }\end{array}$ & $\begin{array}{l}\text { TOPLAM } \\
\text { ÖĞRETIM } \\
\text { UYYESİ }\end{array}$ \\
\hline AMASYA ÜNIVERSITESİ (AÜ) & 0 & 0 & 3 & 3 \\
\hline ATATÜRK ÜNIVERSiTESI (AÜ2) & 0 & 1 & 3 & 4 \\
\hline BURSA TEKNIK ÜNIVERSITESI (BTÜ) & 0 & 0 & 5 & 5 \\
\hline ÇANKAYA ÜNIVERSITESİ (ÇÜ) & 0 & 1 & 3 & 4 \\
\hline KIRKLARELİ ÜNIVERSiTESİ (KÜ) & 1 & 0 & 3 & 4 \\
\hline NECMETTIN ERBAKAN ÜNIV. (NEÜ) & 0 & 2 & 3 & 5 \\
\hline PAMUKKALE ÜNIVERSITESI (PÜ) & 1 & 1 & 1 & 3 \\
\hline TED ÜNIVERSITESİ (TEDÜ) & 0 & 0 & 3 & 3 \\
\hline ÜÇÜNCÜ GRUP ORTALAMA & $\mathbf{0 , 3}$ & $\mathbf{0 , 6}$ & $\mathbf{3}$ & $\mathbf{3 , 9}$ \\
\hline ÜÇÜNCÜ GRUP TOPLAM & $\mathbf{2}$ & $\mathbf{5}$ & $\mathbf{2 4}$ & $\mathbf{3 1}$ \\
\hline
\end{tabular}

\footnotetext{
${ }^{15}$ Üçüncü gruptaki bütün ŞBP bölümlerinin toplam öğretim üyesi sayısı, tek başına İTÜ ŞBP bölümünün öğretim üyesi sayısına eşittir.
} 


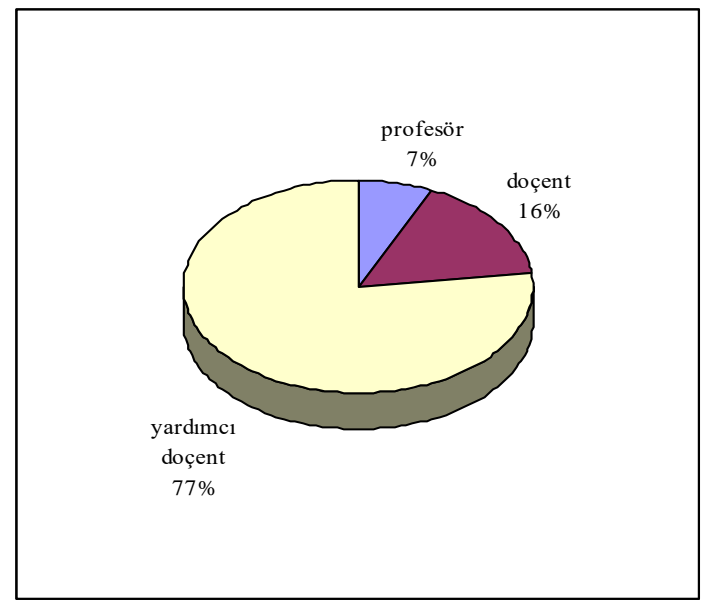

Şekil 3: Üçüncü grup ŞBP bölümlerinde öğretim üyelerinin akademik unvanlara göre dağılımı

$\mathrm{Bu}$ gruptaki öğretim üyelerinin akademik unvanlara göre dağılımına bakıldığında, öğretim kadrolarının yaklaşık 3/4'ünün yardımcı doçentlerden oluştuğu görülmektedir. Öğretim üyelerinin yalnızca \%7'si profesördür. Doçentlerin oran1 \%16'dır (Şekil 3). Üçüncü gruptaki ŞBP bölümlerinde, bölüm başına düşen ortalama profesör ve doçent sayısının toplamı 1'in altındadır $^{16}$. Bu bulgulardan hareketle, üçüncü grup ŞBP bölümleri, genel olarak "profesörsüz ve doçentsiz planlama okulları" olarak tanımlanabilir. Deneyimli kadroların bulunmaması, bu gruptaki ŞBP bölümleri için önemli bir olumsuzluktur.

Üçüncü grup ŞBP bölümlerinde toplam profesör sayısı 2'dir. KÜ ve PÜ ŞBP bölümleri 1 tane profesör ile en çok sayıda profesöre sahip planlama okullarıdır. Gruptaki diğer bölümlerde profesör bulunmamaktadır ${ }^{17}$. Burada temel sorun "yokluk"tur. Üçüncü gruptaki bir ŞBP bölümünde ortalama 0,6 doçent görev yapmakta olup, en çok sayıda doçent NEÜ ŞBP bölümündedir. Bu gruptaki planlama okullarının yarısında doçent bulunmamaktadır ve yarıya yakın bir bölümünün öğretim kadrosu yalnızca yardımcı doçentlerden oluşmaktadır. Her bir ŞBP bölümünde ortalama 3 tane yardımcı doçentin görev yaptığı üçüncü grupta, en çok sayıda yardımcı doçent BTÜ ŞBP bölümünde, en az sayıda yardımcı doçent ise PÜ ŞBP bölümündedir. Bu noktada temel sorun “azlık”tır.

Öğretim kadrosu yeterliliği, bir öğretim üyesi başına düşen azami birinci sene öğrencisi bağlamında incelendiğinde, üçüncü gruptaki ŞBP bölümlerinde kontenjan/öğretim üyesi oranı ortalamasının, bir öğretim üyesi başına 12,1 birinci sene öğrencisi ile TUPOB'un belirlemiş olduğu azami standardın 6 kat üzerinde olduğu görülmektedir (Çizelge 6). $\mathrm{Bu}$ grupta en yüksek kontenjan/öğretim üyesi oranı, bir öğretim üyesi başına 17,3 birinci sene ögrencisi ile AÜ ve PÜ ŞBP bölümlerinde izlenirken, bir öğretim üyesi başına yaklaşık 5,8

\footnotetext{
${ }^{16}$ Üçüncü gruptaki 8 tane planlama okulunda bulunan doçent ve profesörlerin sayısının toplamı tek başına DEÜ ŞBP bölümünün doçent ve profesör sayısına eşittir, İTÜ ŞBP bölümündeki doçent ve profesör sayısının ise 1/3'ünden daha azdır (Çizelge 1 ve Çizelge 5).

17 Üçüncü grupta da ikinci grup ŞBP bölümlerinde olduğu gibi bir anomali vardır. Profesör sayısı bağlamında gruptaki tüm bölümler uç değer özelliği göstermektedir.
} 
birinci sene öğrencisi ile en düşük kontenjan/öğretim üyesi oranı ÇÜ ŞBP bölümünde tespit edilmiştir.

Çizelge 6: Üçüncü grup ŞBP bölümleri kontenjan/öğretim üyesi oranları

\begin{tabular}{|c|c|c|c|}
\hline ÜNIVERSITTE & KONTENJAN & $\begin{array}{l}\text { TOPLAM } \\
\text { ÖĞRETIM } \\
\text { ÜYESİ } \\
\end{array}$ & $\begin{array}{l}\text { KONTENJAN / } \\
\text { ÖĞRETİM } \\
\text { ÜYESİ ORANI }\end{array}$ \\
\hline AMASYA ÜNIVERSİTESİ (AÜ) & 52 & 3 & 17,3 \\
\hline ATATÜRK ÜNIVERSITESİ (AÜ2) & 62 & 4 & 15,5 \\
\hline BURSA TEKNIK ÜNIVERSİTESİ (BTÜ) & 52 & 5 & 10,4 \\
\hline ÇANKAYA ÜNIVERSİTESİ (ÇÜ) & 23 & 4 & 5,8 \\
\hline KIRKLARELİ ÜNIVERSİTESİ (KÜ) & 62 & 4 & 15,5 \\
\hline NECMETTIN ERBAKAN ÜNIVERSİTESİ & 52 & 5 & 10,4 \\
\hline PAMUKKALE ÜNIVERSİTESİ (PÜ) & 52 & 3 & 17,3 \\
\hline TED ÜNIVERSİTESİ (TEDÜ) & 20 & 3 & 6,7 \\
\hline ÜÇÜNCÜ GRUP ORTALAMA & 46,9 & 3,9 & 12,1 \\
\hline
\end{tabular}

Sonuç olarak, üçüncü gruptaki planlama okullarının hiç birisi TUPOB'un belirlemiş olduğu azami kontenjan/öğretim üyesi standardını sağlamamaktadır. Bu durumun en önemli sebebi öğretim üyesi sayısının azlığıdır. İkinci sebebi ise kontenjan sayılarının yüksekliğidir ${ }^{18}$. Genç, hatta emekleme aşamasında olan son nesil ŞBP bölümlerinde gözlemlenen bu çok yüksek kontenjan/öğretim üyesi oranları ile kaliteli bir planlama eğitiminin verilebilmesi, bilimsel faaliyetlerin gerçekleştirilebilmesi ve eğitim-araştırma faaliyetlerinin birlikte sürdürülebilir kılınması mümkün görünmemektedir.

\subsection{Gruplar Arası Karşılaștırma}

Türkiye'de lisans düzeyinde eğitim veren 21 adet ŞBP bölümündeki toplam öğretim üyesi sayıs1 224 olup, ortalama olarak bir ŞBP bölümünde 10,7 öğretim üyesi bulunmaktadır ${ }^{19}$ (Çizelge 7). Bu sayı TUPOB'un belirlediği asgari öğretim üyesi sayısına yakın olmakla birlikte, bu sayının altındadır; diğer bir ifadeyle, planlama okullarının öğretim kadroları, Türkiye genelinde asgari öğretim üyesi sayısı bağlamında yetersizdir. Ancak, öğretim üyesi sayıları gruplar bazında ve ŞBP bölümleri bazında incelendiğinde, ikinci ve üçüncü gruptaki planlama okullarının öğretim kadrolarının Türkiye ortalamasına kıyasla çok daha yetersiz olduğu görülmektedir. Birinci grup ŞBP bölümleri, öğretim üyesi sayısı bağlamında görece

\footnotetext{
${ }^{18} \mathrm{Bu}$ gruptaki ŞBP bölümlerinde kontenjan sayıları her ne kadar birinci ve ikinci gruptaki ŞBP bölümlerine kıyasla daha düşük olsa da TUPOB'un belirlemiş olduğu azami kontenjan standardının üzerindedir.

$19 \mathrm{Bu}$ değer Türkiye genelinde ŞBP bölümlerindeki ortalama öğretim üyesi sayısının 2011 yılına kıyasla küçüldügünü göstermektedir (TUPOB raporunda ŞBP bölümlerindeki ortalama öğretim üyesi sayısı 14'dür).
} 
en iyi durumdadır ${ }^{20}$. Çizelge 7 ve Şekil 4'de sunulan bulgular, öğretim üyesi sayısındaki yetersizliği ve öğretim üyelerinin bölümlere dağılımındaki dengesizliği göstermektedir ${ }^{21}$.

Çizelge 7: ŞBP bölümleri öğretim üyesi sayıları - özet tablo

\begin{tabular}{|c|c|c|c|c|}
\hline ÜNIVERSITE & PROFESÖR & DOÇENT & $\begin{array}{l}\text { YARDIMCI } \\
\text { DOÇENT }\end{array}$ & TOPLAM \\
\hline BİRINCİ GRUP TOPLAM (6 BÖLÜM) & 43 & 46 & 50 & 139 \\
\hline BİRİNCİ GRUP BÖLÜM ORTALAMASI & 7,2 & 7,7 & 8,3 & 23,2 \\
\hline BİRINCİ GRUBUN GENELE ORANI & $\% 88$ & $\% 70$ & $\% 45$ & $\% 62$ \\
\hline İKİNCİ GRUP TOPLAM (7 BÖLÜM) & 3 & 15 & 36 & 54 \\
\hline İKİNCİ GRUP BÖLÜM ORTALAMASI & 0,4 & 2,1 & 5,1 & 7,7 \\
\hline İKİNCİ GRUBUN GENELE ORANI & $\% 6$ & $\% 23$ & $\% 33$ & $\% 24$ \\
\hline ÜÇÜNCÜ GRUP TOPLAM (8 BÖLÜM) & 2 & 5 & 24 & 31 \\
\hline ÜÇÜNCÜ GRUP BÖLÜM ORTALAMASI & 0,3 & 0,6 & 3,00 & 3,9 \\
\hline ÜÇÜNCÜ GRUBUN GENELE ORANI & $\% 6$ & $\% 7$ & $\% 22$ & $\% 14$ \\
\hline TÜRKIYE GENELİ TOPLAM (21 BÖLÜM) & 48 & 66 & 110 & 224 \\
\hline TÜRKIYYE GENELİ BÖLÜM ORTALAMASI & 2,3 & 3,1 & 5,2 & 10,7 \\
\hline
\end{tabular}

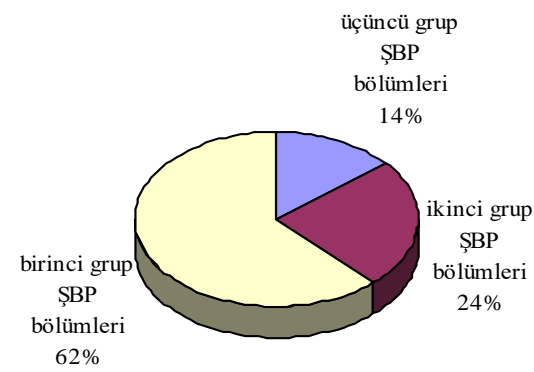

${ }^{20}$ Birinci grup ŞBP bölümlerindeki ortalama öğretim üyesi sayısı TUPOB raporunda 21 iken, 2016 y1lında 23'e yükselmiştir.

21 Örneğin, 8 adet ŞBP bölümünün olduğu üçüncü gruptaki planlama okullarının toplam öğretim kadrosu yalnızca 31 öğretim üyesinden oluşmakta ve bu grupta bir ŞBP bölümü başına ortalama 3,9 öğretim üyesi düşmektedir. Öte yandan, birinci gruptaki bir ŞBP bölümü başına ortalama 23,2 öğretim üyesi düşmektedir. Bu sayı üçüncü grup ŞBP bölümlerindeki ortalama öğretim üyesi sayısının yaklaşık 6 katıdır. 
Şekil 4: Öğretim üyelerinin ŞBP bölümlerine dağılımı

Şekil 5'de öğretim üyelerinin akademik unvanlara göre dağılımı incelendiğinde, öğretim üyelerinin \% 21'inin profesör, \% 30'unun doçent, \% 49'unun yardımcı doçent olduğu görülmektedir. Türkiye genelinde gözlemlenen bu oranlar, akademik unvan çeşitliliği bağlamında olumludur. Ancak akademik unvan çeşitliliği gruplar bazında incelendiğinde, genelden çok farklı dağılımlar tespit edilmiştir (Şekil 1, Şekil 2, Şekil 3).

Özellikle, profesörlerin planlama okullarına dağılımına bakıldığında (Şekil 6), gruplar arasında çok büyük bir dengesizlik dikkati çekmektedir. ŞBP bölümlerindeki profesörlerin \% 88'i birinci grup, \% 6's1 ikinci grup, diğer bir \% 6's1 da üçüncü grup ŞBP bölümlerinde çalışmaktadır. Yani, planlama profesörlerinin neredeyse tamamına yakını (her 10 profesörden 9'u) İstanbul, Ankara ve İzmir'de kurulan ilk grup ŞBP bölümlerindedir. Öte yandan, 21 adet ŞBP bölümünün yarıdan fazlasında hiç profesör bulunmamaktadır (Çizelge 1, Çizelge 2, Çizelge 3).

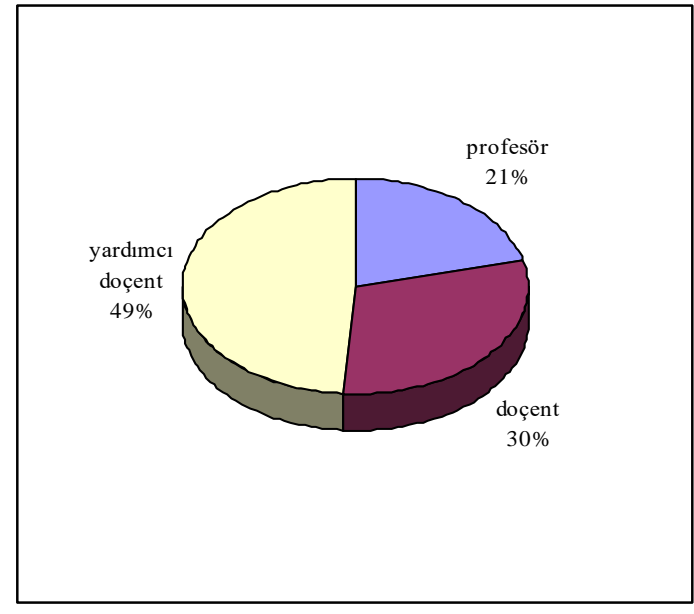

Şekil 5: ŞBP bölümlerinde öğretim üyelerinin akademik unvanlara göre dağılımı 


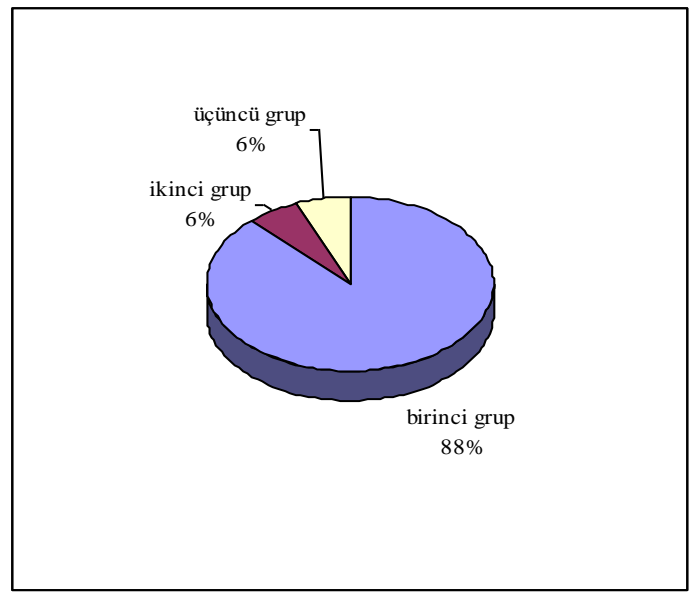

Şekil 6: Profesörlerin ŞBP bölümlerine dağılımı

Benzer bir durum doçentlerin dağılımında da görülmektedir. Planlama okullarındaki doçentlerin $\%$ 70'i birinci grup, \% 23'ü ikinci grup, \% 7'si üçüncü gruptaki ŞBP bölümlerinde istihdam edilmektedir (Şekil 7). Yardımcı doçentlerin ŞBP bölümlerine dağılımının, profesör ve doçentlerin dağılımına kıyasla, görece daha dengeli olduğu söylenebilir (Şekil 8). Sonuç olarak, profesör ve doçentlerin çoğunlukla birinci grup ve ikinci grup ŞBP bölümlerini tercih etmesi neticesinde, üçüncü gruptaki planlama okullarının öğretim kadroları ağırlıklı olarak yardımcı doçentlerden oluşmakta, dolayısıyla da akademik kadro çeşitliliği sunamamaktadır. Özetle, birinci grupta dengeli; ikinci ve üçüncü grup ŞBP bölümlerinde ise dengesiz ve yetersiz bir akademik kadro çeşitliliği görülmektedir.

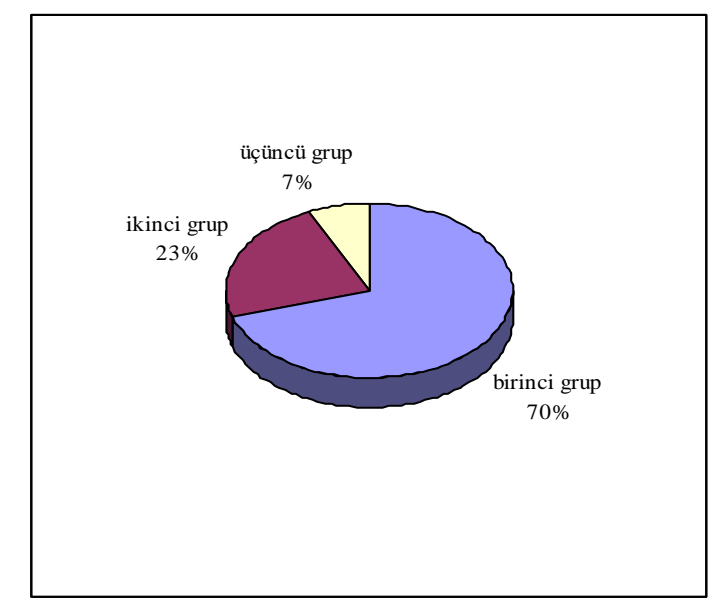

Şekil 7: Doçentlerin ŞBP bölümlerine dağılımı 


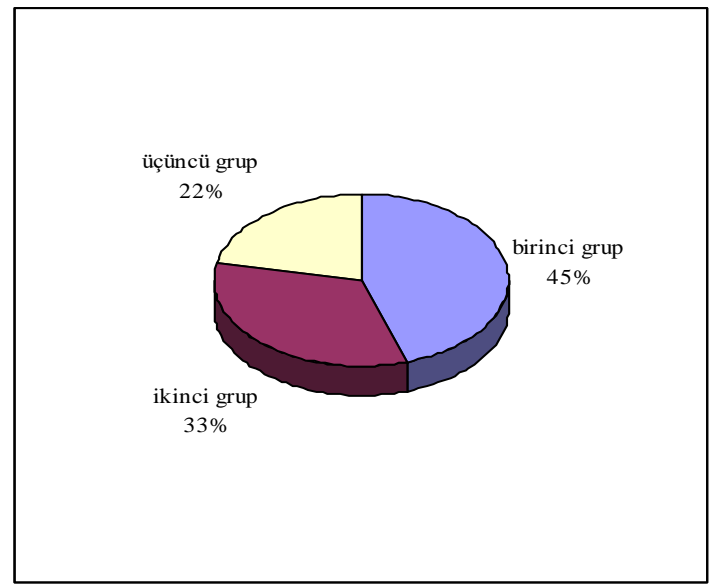

Şekil 8: Yardımcı doçentlerin ŞBP bölümlerine dağılımı

Öğretim üyesi sayıları ve kontenjan sayıları karşılaştırmalı olarak incelendiğinde, öğretim kadrosu yetersizliği sorunu çok daha iyi anlaşılmaktadır. Türkiye genelinde ŞBP bölümlerinde kontenjan/öğretim üyesi oranı ortalaması, bir öğretim üyesi başına 5,5 birinci sene öğrencisidir. Bu oran birinci grup ŞBP bölümlerinde 3,3; ikinci grup ŞBP bölümlerinde 7,6; üçüncü grup ŞBP bölümlerinde ise 12,1'dir. En yüksek kontenjan/öğretim üyesi oran1, bir öğretim üyesi başına 20,7 birinci sene öğrencisi ile ikinci gruptaki BÜ ŞBP bölümünde; en düşük kontenjan/öğretim üyesi oranı ise bir öğretim üyesi başına 2,6 birinci sene öğrencisi ile birinci gruptaki YTÜ ve MSGSÜ ŞBP bölümlerinde tespit edilmiştir (Çizelge 8, ayrıca bkz. Çizelge 2, Çizelge 4, Çizelge 6).

$\mathrm{Bu}$ bulgular, Türkiye genelinde, gruplar bazında ve bölümler bazında kontenjan/öğretim üyesi oranının TUPOB'un belirlemiş olduğu azami kontenjan/öğretim üyesi standardının çok üzerinde olduğunu ve bölümler arasındaki öğrenci yükü dağılımının dengesiz olduğunu göstermektedir. Söz konusu oranın yüksek olmasının önemli bir nedeni kontenjanların çok yüksek olmasıdır. Gruplar arasındaki büyük farklılığın temel nedeni ise; kontenjanların ve öğretim üyelerinin gruplara dağılımının birbiriyle orantısız olmasıdır.

Çizelge 8: ŞBP bölümleri kontenjan/öğretim üyesi oranları - özet tablo

\begin{tabular}{|l|l|l|l|}
\hline & TOPLAM & TOPLAM & $\begin{array}{l}\text { KONTENJAN / } \\
\text { G̈ĞRETIM ÜYYESI } \\
\text { ORANI }\end{array}$ \\
\hline KONTENJAN & ÖĞRETIM ÜYESİ & 3,3 \\
\hline BİINCİ GRUP ŞBP BÖLÜMLERİ & 450 & 139 & 7,6 \\
\hline ÜÇÜNCÜ GRUP ŞBP BÖLÜMLERİ & 413 & 54 & 12,1 \\
\hline ŞBP BÖLÜMLERİ TOPLAMILÜMLERİ & 375 & 31 & $\mathbf{5 , 5}$ \\
\hline
\end{tabular}



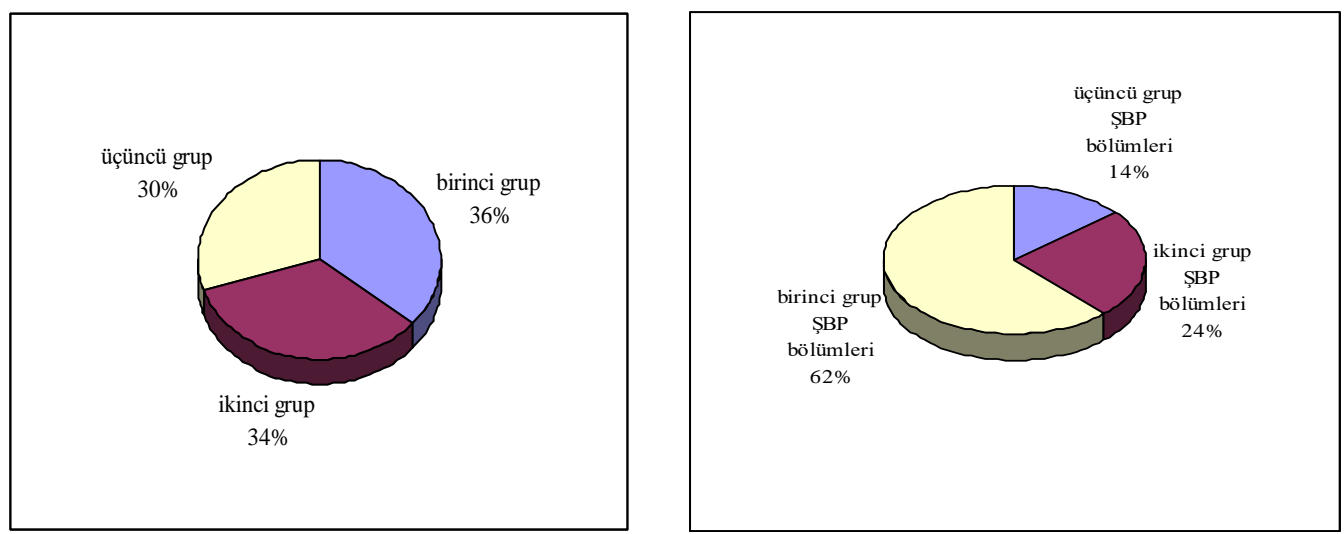

Şekil 9: Sol - Kontenjanların ŞBP bölümlerine dağılımı; Sağ - Öğretim üyelerinin ŞBP bölümlerine dağılımı

Şekil 9 incelendiğinde, kontenjanların ŞBP bölümlerine dağılımı görece dengeli görülmektedir. Ancak, bu dağılım öğretim üyelerinin dağılımı ile birlikte düşünüldüğünde, ŞBP bölümleri arasında kontenjan/öğretim üyesi oranı açısından önemli bir dengesizlik olduğu anlaşılmaktadır. Örneğin, birinci sene öğrencilerinin \%30'unun eğitim görmekte olduğu üçüncü grup ŞBP bölümlerinde çalışan öğretim üyeleri toplam öğretim üyelerinin \%14'ünü oluşturmaktadır. Öte yandan, birinci sene öğrencilerinin \%34'ünün eğitim görmekte olduğu ikinci grup ŞBP bölümlerinde çalışan öğretim üyeleri toplam öğretim üyelerinin \%24'ünü; birinci sene öğrencilerinin \%36'sının eğitim görmekte olduğu birinci grup ŞBP bölümlerinde çalışan öğretim üyeleri toplam öğretim üyelerinin \%62'sini oluşturmaktadır. $\mathrm{Bu}$ oranlar, üçüncü gruptaki öğretim üyeleri üzerindeki öğrenci yükünün birinci gruptakilere göre 4 kat, ikinci gruptakilere göre yaklaşı 2 kat fazla olduğuna işaret etmektedir.

\section{Sonuç}

Bu çalışmada, 2016-2017 öğretim yılı itibariyle, Türkiye'de planlama eğitiminin lisans düzeyinde verildiği ŞBP bölümlerinin öğretim kadrolarının yeterliliği TUPOB'un geliştirdiği asgari ve azami ölçütler bağlamında araştırılmıştır. Bu çerçevede, öğretim üyesi sayıları, akademik unvan çeşitliliği ve kontenjan/ öğretim üyesi oranları Türkiye genelinde ve tek tek bölümler bazında; ayrıca gruplar içinde ve gruplar arasında karşıllaştırmalı olarak incelenmiştir. Bu başlık altında ise, bulguların kısa bir özeti ve değerlendirmesi, ardından politika ve araştırma önerileri sunulmaktadır.

\subsection{Bulguların Özeti ve Değerlendirmesi}

Birinci gruptaki ŞBP bölümleri, her ne kadar asgari öğretim üyesi sayısı ve akademik kadro çeşitliliği ölçütlerini karşılasalar da, bir öğretim üyesi başına düşen azami birinci sene öğrenci sayısı ölçütünü karşılamamaktadırlar. Yüksek kontenjan/öğretim üyesi oranları yanı sıra lisansüstü öğretim yükleri ve üstlendikleri diğer roller göz önüne alındığında, Türkiye'nin en eski, en köklü planlama okullarının yer aldığı birinci gruptaki ŞBP 
bölümlerinin öğretim kadrolarının yeterli olduğunu söylemek mümkün değildir. İkinci gruptaki ŞBP bölümleri ise, ne asgari öğretim üyesi sayısı ölçütünü, ne akademik kadro çeşitliliği ölçütünü, ne de bir öğretim üyesi başına düşen azami birinci sene öğrenci sayısı ölçütünü karşılamaktadırlar. TUPOB'un bu gruptaki ŞBP bölümlerine ilişkin 2011'de dikkat çektiği öğretim kadrosu yetersizliği sorunu hala aşılamamıştır. Birçoğu genç bir bölüm olma vasfını çoktan aşmış olan ikinci grup planlama bölümlerinde gözlenen bu durum, eğitimde kalitenin sağlanabilirliği ve sürdürülebilirliği bağlamında düşündürücüdür. İkinci grup planlama bölümlerine benzer şekilde, üçüncü grup ŞBP bölümleri de TUPOB'un geliştirdiği ölçütlerin hiç birini karşılamamaktadır. Bu planlama okullarının öğretim kadroları sayısal olarak çok yetersizdir. Üçüncü gruptaki ŞBP bölümleri, TUPOB'un 2011 yılında hazırladığı rapordan sonra lisans eğitimine başlamışlardır. Ancak, bu genç planlama okullarının öğretim kadrolarının şekillendirilmesi ve kontenjanlarının belirlenmesi noktasında TUPOB ölçütlerinin olumlu bir etkisinin olmadığı görülmektedir. Özetle, TUPOB'un belirlemiş olduğu asgari ve azami standartların tamamını karşılayan hiçbir grup ve hiçbir planlama okulu yoktur.

Sonuç olarak, araştırmanın ortaya koyduğu bulgular ışığında denilebilir ki; ŞPB bölümlerinin öğretim kadroları TUPOB ölçütlerine göre yetersizdir. Ancak, yetersizliğin dereceleri farklıdır, üçüncü grup ŞBP bölümleri tüm ölçütlere göre en dezavantajlı durumdaki gruptur. Ayrıca öğretim üyelerinin ŞBP bölümlerine dağılımında büyük bir dengesizlik vardır. $\mathrm{Bu}$ dengesizliğin temel nedeni, öğretim üyesi arzının ŞBP bölümlerinin ihtiyacı olan öğretim üyesi sayısını karşılayamamasıdır. Ayrıca, 2016-2017 öğretim yılı itibariyle, Türkiye genelinde ŞPB bölümlerinin öğretim kadrosu yeterliliği TUPOB'un 2011 yılında yapmış olduğu tespitlerin gerisindedir. $\mathrm{Bu}$ sonuçlar, TUPOB ölçütlerinin ŞBP bölümlerinin yapılandırılmasında belirleyici olamadığını göstermektedir.

\subsection{Politika Önerileri}

Bulgular, kaliteli bir planlama eğitiminin ve bilimsel araştırma ortamının sağlanabilmesi ve sürdürülebilmesi için, tüm ŞBP bölümlerinde öğretim kadrolarının ivedilikle iyileştirilmesi gerektiğine işaret etmektedir. Bu çerçevede; birinci grup planlama okullarında bir yandan kontenjan sayıları yarı yarıya düşürülmeli diğer yandan öğretim üyesi sayıları, yardımcı doçent sayısının artırılması yoluyla yükseltilmelidir. İkinci ve üçüncü grup ŞBP bölümlerinde ise, bir yandan kontenjan sayıları düşürülmeli diğer yandan öğretim üyesi sayıları akademik kadro çeşitliliği sağlayacak şekilde ivedilikle yükseltilmelidir. Özetle, tüm ŞBP bölümlerinde bir yandan öğretim üyesi sayıları artırılmalı, diğer yandan kontenjanlar düşürülmelidir. Ayrıca, deneyimli kadrolardan mahrum olan ikinci ve üçüncü grup planlama okullarında akademik kadro çeşitliliği yeterli bir düzeyde sağlanmalıdır.

Ancak, ülkedeki plancı öğretim üyesi arzı ve talebi arasındaki dengesizlik giderilmeden, ŞBP bölümlerinde öğretim kadrolarının yeterli hale getirilebilmesi - kontenjanlar TUPOB standartlarına uygun bir seviyeye getirilse dahi - mümkün değildir. Dolayısıyla, öncelikle arz ve talep dengesinin sağlıklı bir şekilde kurulması gereklidir. Bunun için, birinci grup ŞBP bölümlerinde lisansüstü eğitime azami ölçüde odaklanılarak doktoralı şehir plancısı arzı hızla artırılmalı ve bu arzın bütün planlama okullarına dengeli bir şekilde dağılması sağlanmalıdır. Ayrıca, TUPOB ölçütlerinin tavsiye niteliğinden çıkarılıp, yasal bağlayıcılığı 
olan hükümlere dönüştürülmesi ivedilikle başarılmalıdır ${ }^{22}$. Aksi takdirde, ilerleyen yıllarda, öğretim kadrosu yetersizliğinin ve bunun neden olacağı sonuçların çok daha ileri boyutlarda bir sorun olarak yaşanılması kaçınılmazdır. Bu noktada tüm planlama okullarına önemli sorumluluklar düşmektedir.

\subsection{Araştırma Önerileri}

ŞBP bölümlerinin TUPOB ölçütlerine göre yeterliliği ve TUPOB ölçütlerinin yeni ŞBP bölümlerinin yapılandırılmasında ne düzeyde etkili olduğu, fiziki altyap1 ve diğer bağlamlarda da gruplamalı bir şekilde araştırılmalıdır. Ayrıca, kaliteli bir eğitim için gerekli olan asgari ve azami ölçütler, karar süreçlerinde etkili olabilecek nitelikte yeniden geliştirilmelidir. Bu yeniden geliştirme, şu tartışmaların ışığında yapılmalıdır.

- Mevcut TUPOB ölçütlerinin yeterliliği: TUPOB'un öğretim kadrosu, fiziki altyap1 ve coğrafi erişilebilirliğe ilişkin belirlediği ölçütler, bir planlama okulunun lisans düzeyinde eğitim verebilmesi için gerekli asgari ve azami standartlardır. Ancak, bu ölçütlerin yalnızca lisans eğitimi veren planlama okulları ile lisans, yüksek lisans ve doktora olmak üzere eğitimin her kademesinde faaliyet gösteren ve eğitimin yanı sıra bilimsel-mesleki organizasyonlara öncülük eden planlama okullarına eşit bir şekilde uygulanmasının ne kadar sağlıklı olduğu tartışılmalıdır. Mevcut ölçütlerin yalnızca lisans düzeyinde eğitim veren ŞBP bölümlerini yapılandırma ve değerlendirmedeki yeterliliği de tartışılmalıdır. Bu çerçevede, örneğin öğretim kadrosu yeterliliği bağlamında, yardımcı öğretim elemanlarının konumu, şehir planlama mesleğinin farklı uzmanlık alanları ve farklı disiplinler ile ilişkileri dikkate alınmalidır.

- TUPOB ölçütlerinin bilimsel dayanakları: TUPOB ölçütleri bir ortak akıl çalışması ürünü olması bakımından çok önemli ve değerlidir, ancak mevcut ölçütlerin bilimsel dayanaklarının söz konusu raporda ne kadar yeterli bir seviyede açıklanabildiği, bu ölçütlerin karar süreçlerinde etkili olabilmesi için bilimsel dayanaklarının daha güçlü bir şekilde nasıl açıklanabileceği tartışılmalıdır.

- Mimarlık Fakültesi bölümleriyle işbirliği: Fakülte bazlı ölçütlerin karar süreçlerindeki etkililiğinin bölüm bazlı ölçütlere göre daha yüksek olacağ varsayımından hareketle, ŞBP bölümleri özelinde münferit ölçütler geliştirmek yerine, Mimarlık Fakültesi çatısı altında benzer eğitim süreçleri olan, benzer ihtiyaçları olan, eğitiminin merkezinde stüdyo dersleri yer alan Mimarlık ve diğer bölümler ile işbirliği içinde, ortak ölçütlerin nasıl geliştirilebileceği tartışılmalıdır.

\footnotetext{
22 Eğitimin farklı düzeyleri, yardımcı öğretim elemanları, uzmanlık alanları, bilimsel dayanaklar, disiplinerarası ilişskiler ve işbirliği vb tartışmaların ışı̆̆ında geliştirilecek ölçütlerin politika yapıcıları ve karar vericileri ikna etme gücü daha yüksek olacaktır. Bu çerçevede, araştırma önerileri başlı̆̆ altında açıklanan hususlar irdelenmelidir.
} 


\section{Kaynakça}

ACAR, M. (2012) Üniversitelerde Yeniden Yapılanmanın Aciliyeti ve Yeni Üniversitelerin Sorunları, Eğitime Baklş Dergisi, Sayı: 8(23), s: 21-27

ALTINSOY, S. (2011) Yeni Devlet Üniversitelerinin Gelişimi: Sorunlar ve Politika Önerileri, Yükseköğretim ve Bilim Dergisi, Sayı: 1(2), s: 98-104

ANDERBERG, E.; NORDEN, B.; HANSSON B. (2009) Global Learning for Sustainable Development in Higher Education: Recent Trends and a Critique, International Journal of Sustainability in Higher Education, Say1: 10(4), s: 368-378

ARAP, K. (2010) Türkiye Yeni Üniversitelerine Kavuşurken: Türkiye'de Yeni Üniversiteler ve Kuruluş Gerekçeleri, Ankara Üniversitesi SBF Dergisi, Sayı: 65(1), s: 10-25

ARSLAN, R. (1991) Kent ve Bölge Planlama Eğitiminde Dikkate Alınması Gerekli İlkeler Üzerine, Şehircilik - Planlama Eğitimi, 13. Şehircilik Günü Kolokyumu (6-7-8 Kasım, 1989), Yıldız Teknik Üniversitesi Yayını, Edit: DİNÇER, İ.; YENEN, Z., İstanbul

ARU, K. A. (2001) Bir Üniversite Hocasının Yaşamının 80 Yılı, Yapı Endüstri Merkezi Yayınları, İstanbul

AMASYA ÜNIVERSITESİ, Şehir ve Bölge Planlama Bölümü, [http://www.amasya.edu.tr/akademik/fakülteler/mimarlık-fakultesi/bolumsayfalari/sehir-ve-bolge-planlama-bolumu/hakkimizda.aspx] Erişim Tarihi (01.10.2016).

ATATÜRK ÜNIVERSITESI, Şehir ve Bölge Planlama Bölümü, [http://www.atauni.edu.tr/sehir-ve-bolge-planlama-bolumu-4] Erişim Tarihi (03.10.2016).

BOZOK ÜNIVERSITESİ, Şehir ve Bölge Planlama Bölümü,[http://mmf.bozok.edu.tr/tr/sbp] Erişim Tarihi (03.10.2016).

BURSA TEKNIK ÜNIVERSITESI, Şehir ve Bölge Planlama Bölümü, [http://sehir.btu.edu.tr/index.php] Erişim Tarihi (06.10.2016).

BÜYÜKCIVELEK, B. (2016) Neoliberal Düzende Üniversite, Şehir Planlama Eğitimi ve Devrimci Planlama Üzerine Bir Deneme: ODTÜ Şehir ve Bölge Planlama Örneği, Müdahale, Mücadele ve Planlama, Kolokyum Bildirileri (8 Kasım Dünya Şehircilik Günü 39. Kolokyumu, 5-6-7-8 Kasım 2015), Karadeniz Teknik Üniversitesi, Trabzon; 597-613.

CÖMERTLER, S. (2016) 55. Yılında Türkiye'de Şehir ve Bölge Planlama Bölümleri, Şehircilik ve Eğitimi, (8. Türkiye Şehircilik Kongresi, 6-7-8 Kasım 2016), Orta Doğu Teknik Üniversitesi, Ankara (Bildiri Kitabı basım aşamasında).

ÇANKAYA ÜNIVERSiTESİ, Şehir ve Bölge Planlama Bölümü, [http://crp.cankaya.edu.tr/] Erişim Tarihi (02.10.2016).

DOKUZ EYLÜL ÜNIVERSITESI, Şehir ve Bölge Planlama Bölümü, [http://mimarlik.deu.edu.tr/sehir_bolge_planlama] Erişim Tarihi (01.10.2016).

DOĞAN, D. (2013) Yeni Kurulan Üniversitelerin Sorunları ve Çözüm Önerileri, Yüksekögretim ve Bilim Dergisi, Sayı: 3(2), s: 108-116 
DURSUN, D. (2016) Türkiye'de Yüksek Öğretim Politikası ve Yeni Kurulan Şehir ve Bölge Planlama Bölümleri: Atatürk Üniversitesi Şehir ve Bölge Planlama Bölümü Deneyimi, Şehircilik ve Ĕ̈itimi, (8. Türkiye Şehircilik Kongresi, 6-7-8 Kasım 2016), Orta Doğu Teknik Üniversitesi, Ankara (Bildiri Kitabı basım aşamasında).

ENLİL, Z. M. (2001) Avrupa Birliği’nde Yüksek Öğretimde Yeni Arayışlar, Ortaklaştırılan Pratikler ve İngiltere'de Planlama Eğitimine Yansımaları, Avrupa Birliği Süreci ve Planlama, 5. Türkiye Şehircilik Kongresi (7-9 Kasım 2001), TMMOB Şehir Planciları Odası, Ankara

ERCIYES ÜNIVERSITESİ, Şehir ve Bölge Planlama Bölümü, [http://mimarlik.erciyes.edu.tr/icerikler/sehir-ve-bolge-planlama] Erişim Tarihi (03.10.2016).

ERBAŞ, E. (2002) Şehir ve Bölge Planlama Bölümleri İle İlgili Verilerin Değerlendirilmesi, Planlama Eğitimini Yeniden Düşünmek, II. Planlama Kongresi (7-8 Şubat 2002), Edit: TURGUT, S.; ÖZDEN, P.; KARAKAŞ, İ.; GÜL, A.; ERDEM, D., Yıldız Teknik Üniversitesi Yayını, İstanbul

ERCOŞKUN, C.; YALÇINER, Ö. (2002) Avrupa'da ve Türkiye'de Değişen Planlama Eğitimi, Planlama Eğitimini Yeniden Düşünmek, II. Planlama Kongresi (7-8 Şubat 2002), Edit: TURGUT, S.; ÖZDEN, P.; KARAKAŞ, İ.; GÜL, A.; ERDEM, D., Yıldız Teknik Üniversitesi Yayını, İstanbul

ERDEM, A. R. (2012) Küreselleşme: Türk Yükseköğretimine Etkisi, Yükseköğretim Dergisi, Sayı: 2(2), s: 109-117

ERDEM, A. R. (2006) Dünyadaki Yükseköğretimin Değişimi, Selçuk Üniversitesi Sosyal Bilimler Enstitüsü Dergisi, Sayı: 15, s: 299-314

ESMER, Ö. (1991) ODTÜ Şehir ve Bölge Planlama Bölümünün 30 Yıllık Tarihi Üzerinde Gözlem ve Düzeltmeler, Türkiye'de Şehirciliğin Gelişiminde Son 30 Yllın Değerlendirilmesi, 3. Türkiye Şehircilik Kongresi (6-7-8 Kasım 1991), İzmir

GAZİ ÜNIVERSITESİ, Şehir ve Bölge Planlama Bölümü, [http://mim-sbp.gazi.edu.tr/] Erişim Tarihi (05.10.2016).

GÜLERSOY, Z. (2007) Türkiye'de Şehir ve Bölge Planlama Eğitiminde Kalite Geliştirme ve Akreditasyon ve Mesleki Yetkinlik Yeterlilik, Türkiye Planlama Okulları Birliği III. Koordinasyon Toplantısı Raporu, Derleyen: GÜLERSOY, N. Z.; KUNDAK, S.; GÜNAY, Z., İstanbul Teknik Üniversitesi, İstanbul

GÜNAY, D. (2011) Türk Yükseköğretiminin Yeniden Yapılandırılması Bağlamında Sorunlar, Eğilimler, İlkeler ve Öneriler - I, Yüksekögretim ve Bilim Dergisi, Sayı: 1(3), s: 113-121

GÜNAY, D.; GÜNAY A. (2016) Dünyada ve Türkiye'de Yükseköğretimde Okullaşma Oranları ve Gelişmeler, Yükseköğretim ve Bilim Dergisi, Say1: 6(1), s: 13-30

HAMMOND, C., CHURCHMAN D (2008) Sustaining Academic Life: A Case for Applying Principles of Social Sustainability to the Academic Profession, International Journal of Sustainability in Higher Education, Say1: 9(3), s: 235-245

İNANKUL, Ş. (1991) Planlama ve Planlama Eğitimi Üzerine, Şehircilik - Planlama Eğitimi, 13. Şehircilik Günü Kolokyumu (6-7-8 Kasım, 1989), Yıldız Teknik Üniversitesi Yayını, Edit: DİNÇER, İ.; YENEN, Z., İstanbul 
İSTANBUL TEKNIK ÜNIVERSITESI, Şehir ve Bölge Planlama Bölümü, [http://sehirbolge.itu.edu.tr/] Erişim Tarihi (04.10.2016).

IZMIR YÜKSEK TEKNOLOJİ ENSTITÜSÜ, Şehir ve Bölge Planlama Bölümü, [http://city.iyte.edu.tr/] Erişim Tarihi (04.10.2016).

KARADENIZ TEKNIK ÜNIVERSiTESI, Şehir ve Bölge Planlama Bölümü, [http://www.ktu.edu.tr/sehircilik] Erişim Tarihi (03.10.2016).

KARAHAN, Ö., KARAHAN A.Y. (2012) Üniversitelerin Meseleleri, Yükseköğretim Dergisi, Say1: 2(2), s: 80-84

KAVAK, Y. (2011a) Türkiye'de Yükseköğretimde Büyüme: Yakın Geçmişe Bakış ve Uzun Vadeli (2010-2050) Büyüme Projeksiyonları, Yükseköğretim Dergisi, Say1: 1(2), s: 95-102

KAVAK, Y. (2011b) Türkiye'de Yükseköğretimin Görünümü ve Geleceğe Bakış, Yüksekögrretim ve Bilim Dergisi, Say1: 1(2), s: 55-58

KELEŞ, R. (1987) Türkiye'de Kentbilim Eğitimi, Ankara Üniversitesi Siyasal Bilgiler Fakültesi Yayını, Ankara

KIRKLARELİ ÜNIVERSITESİ, Şehir ve Bölge Planlama Bölümü, [http://sbp.klu.edu.tr/] Erişim Tarihi (01.10.2016).

MERSIN ÜNIVERSITESI, Şehir ve Bölge Planlama Bölümü, [http://www.mersin.edu.tr/akademik/mimarlıkfakultesi/bolumler/sehir-ve-bolgeplanlama-bolumu] Erişim Tarihi (01.10.2016).

MIMAR SINAN GÜZEL SANATLAR ÜNIVERSITESİ, Şehir ve Bölge Planlama Bölümü, [http://www.msgsu.edu.tr/faculties/mimarlik-fakultesi/sehir-ve-bolge-planlamabolumu1] Erişim Tarihi (02.10.2016).

NECMETTIN ERBAKAN ÜNIVERSITESİ, Şehir ve Bölge Planlama Bölümü, [https://konya.edu.tr/sehirvebolge planlama] Erişim Tarihi (05.10.2016).

ORTA DOĞU TEKNIK ÜNIVERSITESİ, Şehir ve Bölge Planlama Bölümü, [http://crp.metu.edu.tr/] Erişim Tarihi (05.10.2016).

OSYM, 2016-ÖSYS Yükseköğretim Programları ve Kontenjanları Kılavuzu (Tablo-4), [http://www.osym.gov.tr/TR,12454/2016-osys-yuksekogretim-programlari-vekontenjanlari-kilavuzu.html] Erişim Tarihi (01.10.2016).

ÖZER, A. (2012) Türkiye Üniversite Sistemine Genel Bir Bakış, Yaşanan Sorunlar ve Çözüm İçin Bir Model Önerisi, Yükseköğretim Dergisi, Sayı: 2(2), s: 61-72

ÖZER, A. (2011) Türkiye'de Yükseköğretimde Büyüme ve Öğretim Üyesi Arzı, Yüksekögretim ve Bilim Dergisi, Say1: 1(1), s: 23-26

ÖZOĞLU, M.; GÜR, B. S.; GÜMÜŞ, S. (2016) Rapid Expansion of Higher Education in Turkey: The Challenges of Recently Established Public Universities (2006-2013), Higher Education Policy, Say1: 29(1), s: 21-39

PAMUKKALE ÜNIVERSITESI, Şehir ve Bölge Planlama Bölümü, [http://www.pau.edu.tr/mtf/tr] Erişim Tarihi (03.10.2016).

REHBER, E. (2007) Dünyada Değişen Yükseköğretim ve Kalite Anlayışı, Değişim Çağında Yükseköğretim, Yaşar Üniversitesi Yayınları, İzmir 
SCHOFER, E.; MEYER, J. W. (2005) The Worldwide Expansion of Higher Education in the Twentieth Century, American Sociological Review, Say1: 70(6), s: 898-920

SELÇUK ÜNIVERSITESI, Şehir ve Bölge Planlama Bölümü, [http://www.selcuk.edu.tr/mimarlik/sehir_ve_bolge_planlama/tr] Erişim Tarihi (09.10.2016).

SÜLEYMAN DEMIREL ÜNIVERSITESI, Şehir ve Bölge Planlama Bölümü, [http://mimarlik.sdu.edu.tr/tr/bolumler/sehir-ve-bolge-planlama-4937s.html] Erişim Tarihi (09.10.2016).

TED ÜNIVERSITESİ, Şehir ve Bölge Planlama Bölümü, [http://city.tedu.edu.tr/tr/city] Erişim Tarihi (05.10.2016).

TEKELİ, İ. (2003) Eğitim Üzerine Düşünmek, Türkiye Bilimler Akademisi Yayınları, Ankara

TEKELİ, İ. (1987) ODTÜ'de Şehir ve Bölge Planlama Eğitimi, Türkiye'de Kentbilim Eğitimi, Edit: KELEŞ, R., Ankara Üniversitesi Siyasal Bilgiler Fakültesi Yayını, Ankara, s: 65-90

TEKNECI, P. D. (2016) Evaluation of Turkish Higher Education System in the Last Decade, Yüksekögretim ve Bilim Dergisi, Sayı: 6(3), s: 277-287

TUPOB (2011) Lisans Düzeyinde Açılacak Şehir ve Bölge Planlama Bölümleri İçin Gerekli Asgari Ölçütler, [http://www.spo.org.tr/resimler/ekler/0da2e7510a2c0b6_ek. pdf?tipi $=56 \&$ turu $=\mathrm{H} \&$ sube $=0$ ] Erişim Tarihi (17.06.2016).

TUPOB (2007) Türkiye'de Şehir ve Bölge Planlama Eğitiminde Kalite Geliştirme ve Akreditasyon, Türkiye Planlama Okulları Birliği III. Dönem Çalışmaları Raporu, Hazırlayan: GÜLERSOY, N. Z.; KUNDAK, S.; GÜNAY, Z.; DEMIRCİOĞLU, E.; YAZGI, B.; BEYAZIT, E.; GÖNÜL, D., İstanbul Teknik Üniversitesi, İstanbul

TUPOB (2005) TUPOB Türkiye Planlama Okulları Birliği 1. Koordinasyon Toplantıst, Hazırlayan: TURGUT, S.; ERKAN, N.; KURTARIR, E., Yıldız Teknik Üniversitesi ve TMMOB Şehir Plancıları Odası Yayını, İstanbul

TURAL, N. K. (2004) Küreselleşme ve Üniversiteler, Kök Yayıncılık, Ankara

YILDIZ TEKNIK ÜNIVERSITESİ, Şehir ve Bölge Planlama Bölümü, [http://www.sbp.yildiz.edu.tr/\#] Erişim Tarihi (01.10.2016).

YILDIZ TEKNIK ÜNIVERSITESİ (2008) Şehircilik ve Proje Kürsüsünden Şehir ve Bölge Planlama Bölümüne, Hazırlayan: DİNÇER, İ; AKIN, O.; YAKAR, H.; OĞUZTIMUR, S.; SEÇILMIŞLER, T.; KURTARIR, E.; SINMAZ, S., Yıldız Teknik Üniversitesi Yayını, İstanbul

YILDIZ TEKNIK ÜNIVERSITTESİ (1991) Şehircilik - Planlama Eğitimi, 13. Şehircilik Günü Kolokyumu (6-7-8 Kasım, 1989), Yıldız Teknik Üniversitesi Yayını, Edit: DINNÇER, İ.; YENEN, Z., İstanbul

YILMAZ, D. V. (2013) Yükseköğretimin Değişen Bağlamı: 21. Yüzyılda Dönüşümler ve Eğilimler, Yükseköğretim Dergisi, Sayı: 3(3), s: 169-176 